\title{
Institutional Investors' Horizons and Corporate Employment Decisions
}

\author{
Mohamed Ghaly* \\ Lancaster University \\ Viet Anh Dang \\ Alliance Manchester Business School \\ Konstantinos Stathopoulos \\ Alliance Manchester Business School
}

\begin{abstract}
Monitoring by long-term investors should reduce agency conflicts in firms' labor investment choices. Consistent with this argument, we find that abnormal net hiring, measured as the absolute deviation from optimal net hiring predicted by economic fundamentals, decreases in the presence of institutional investors with longer investment horizons. Firms dominated by long-term shareholders reduce both over-investment (over-hiring and under-firing) and underinvestment (under-hiring) in employees. The monitoring role of long-term investors is stronger for firms facing higher labor adjustment costs both in absolute terms and relative to capital adjustment costs, and those for which human capital is regarded as more important. The effect is also more pronounced for firms that have stronger incentives and/or more opportunities to deviate from expected net hiring. We address endogeneity concerns by exploiting exogenous changes to long-term institutional ownership resulting from annual reconstitutions of the Russell indexes.
\end{abstract}

JEL Classifications: G23, G32, G34, M51.

Keywords: Institutional ownership, Investment horizon, Employment, Investment efficiency, Corporate governance, Monitoring.

\footnotetext{
*Corresponding author: Mohamed Ghaly, Email: m.ghaly@lancaster.ac.uk, Tel: +44(0) 1524 594526, Address: Accounting and Finance Department, Lancaster University Management School, Bailrigg, Lancaster, LA1 4YX, United Kingdom. We thank Sudipto Dasgupta, Marie Dutordoir, Susanne Espenlaub, Todd Gormley, Hans Hvide, Arif Khurshed, Ambrus Kecskés, Mauricio Larrain, Michelle Lowry, Maria Marchica, Roberto Mura, Anil Shivdasani, Weiqang Tan, Karin Thorburn, Hai Tran, Anh L. Tran, Josep Tribó, Ralph Walkling, participants at the 2015 Vietnam International Conference in Finance (VICIF), the 2015 Financial Management Association Annual Meeting, the 2016 International Corporate Governance Society Annual Conference, the 2016 World Finance Conference, the 2017 Annual Corporate Finance Conference, as well as seminar participants at Athens University of Economics and Business, Drexel University, Essex Business School, HEC Lausanne, Lancaster University, Universitat de les Illes Balears, University of Cyprus, and University of Miami, for helpful comments and suggestions on earlier drafts of this paper.
} 


\section{Introduction}

Recent research has underscored the importance of corporate employment decisions, particularly the need for firms to maintain optimal investment in employees (Pinnuck and Lillis, 2007; Falato and Liang, 2016; Ellul et al., 2018). Divergence from optimal labor investment is costly to a firm since it leads to over-capacity problems, and thus lower productivity, in the case of over-investment, or insufficient growth in the case of underinvestment (Williamson, 1963; Stein, 1989). These problems are likely to be more acute in modern firms since they are more human-capital intensive (Pfeffer, 1996; Zingales, 2000) and invest heavily in labor. ${ }^{1}$ Indeed, anecdotal evidence suggests that shareholders, and particularly institutional investors, appreciate the importance of labor investments. For example, a coalition of institutional investors with over $\$ 2.8$ trillion under management recently petitioned the Securities and Exchange Commission (SEC) to introduce rules requiring firms to enhance disclosure on their human capital management policies. ${ }^{2}$ Also, BlackRock publishes an annual report detailing its approach to engagement on human capital management, which lists voluntary and involuntary turnover as well as employee tenure as topics it covers when engaging with the management teams of firms in its portfolio. ${ }^{3}$ In this paper, we study whether monitoring, or even the threat of monitoring, by institutional investors, particularly those with long investment horizons, mitigates agency conflicts associated with employment decisions and thus reduces labor investment inefficiency.

\footnotetext{
${ }^{1}$ The Annual Survey of Manufacturers reports that payroll and employee benefits in the U.S. manufacturing sector totaled $\$ 828$ billion in 2015 , compared to $\$ 175$ billion in capital expenditure. The survey is available at https://www.census.gov/data/tables/2015/econ/asm/2015-asm.html.

2 On July 6 2017, the SEC received a petition for rulemaking (File No. 4-711) urging the adoption of standards requiring firms to disclose information on their human capital management policies, practices, and performance. The petition was submitted by the Human Capital Management Coalition, which is an initiative supported by 25 influential institutional investors, including some of the largest pension funds.

3 The most recent report is available at https://www.blackrock.com/corporate/literature/publication/blkcommentary-engagement-on-human-capital.pdf
} 
An important factor that should affect the willingness of an institutional investor to engage in monitoring is the time horizon of his/her investment. Institutional shareholders can vary in their investment horizons because of differences in their trading strategies and/or the maturities of their liabilities. Many hedge funds and open-ended mutual funds, for example, are short term as a result of their trading strategies and their high liquidity needs, whereas pension funds and insurance companies usually have long horizons because of the longer maturities of their liabilities (Yan and Zhang, 2009; Derrien et al., 2013). As in Gaspar et al. (2005) and Chen et al. (2007), we argue that long-term investors enjoy economies of scale in collecting and processing corporate information. These investors have lower monitoring cost functions since they build firm- and manager-specific knowledge over time. This knowledge helps them benefit from monitoring by increasing their ability to influence managers, as well as enhancing the quality of the information they collect, which could be used to inform future trading decisions (Chen et al., 2007). This argument is in line with McCahery et al.'s (2016) survey evidence on the importance of investment horizons in explaining institutional investors' engagement with their portfolio firms. Therefore, we frame the underlying conflict under investigation as an agency problem between managers and long-term shareholders.

Inefficiencies in human-capital investments can take the form of over- and/or underinvestment in labor. Over-investment in labor takes place when agency conflicts lead selfinterested managers to engage in over-hiring activities as part of their empire-building agendas. Williamson (1963) specifically uses the expansion of staff numbers beyond optimal levels as an example of managers' opportunistic behavior aimed at gaining more security and power. Over-investment in labor also occurs when managers decide to retain (under-fire) poorly performing employees as a mutually beneficial arrangement. Bertrand and Mullainathan (2003) show that managers may be reluctant to trim an unproductive workforce because of their preference for the quiet life and their desire to avoid the difficult decisions and costly 
effort associated with downsizing. Pagano and Volpin (2005) demonstrate that top managers facing potential dismissal for poor performance may form an alliance with the workforce by abstaining from worker layoffs and wage cuts. Workers, in return, may help retain such managers if they have sufficient power to affect such decisions. Similarly, Atanassov and Kim (2009) show that weak investor protection combined with strong union laws leads to workermanagement alliances, in which poorly performing firms sell assets to prevent large-scale layoffs, garnering worker support for retaining the management. Landier et al. (2009) find that firms in the U.S. are less likely to lay off workers located geographically closer to the corporate headquarters, and that this behavior may, in part, reflect private benefits to CEOs that come from interacting with workers and communities close to the corporate headquarters.

Under-investment in labor, on the other hand, occurs when pressure from outside investors leads managers to over-fire underperforming employees or to under-hire to meet earnings targets. As stressed by Narayanan (1985), Stein (1989), Froot et al. (1992), Porter (1992), and Von Thadden (1995), myopic pressures from outside investors can result in managers turning down valuable investment opportunities due to concerns over the firm's short-term stock price. Therefore, a manager concerned with short-term results can end up under-investing in labor out of fear that such investments would depress earnings and adversely affect stock prices (Porter, 1992; Bushee, 1998). Empirical evidence produced by Graham et al. (2005) reports that a significant number of managers are willing to give up projects that will be profitable in the long run to meet short-run earnings targets. Of most relevance to our context is their finding that firms can postpone or eliminate hiring to avoid missing earnings targets.

Motivated by the abundant evidence on the agency conflicts associated with labor investments, we argue that the existence of long-term institutional investors in a firm's ownership structure can help mitigate these conflicts. We hypothesize that, in firms with longer 
investor horizons, direct monitoring or the threat of monitoring by long-term investors should result in fewer sub-optimal investments in employees.

To capture the investment horizon of a firm's shareholders, we follow the literature (Gaspar et al., 2005; Yan and Zhang, 2009; Cella et al., 2013) and measure the investment horizon of each institutional shareholder using his/her portfolio turnover level. We then aggregate individual turnover rates within each firm to get the (weighted) average portfolio turnover rate of all institutional investors with positive shareholdings in the firm. To ensure that higher values of our horizon proxy correspond to a longer investment horizon and to simplify the interpretation of our results, we multiply the investor turnover measure by -1 . We call this proxy Investor_Stability and use it in subsequent analysis to study how the investment horizon of a firm's institutional shareholders affects the efficiency of its labor investments.

Based on the economics literature (e.g., Hamermesh, 1989) and recent empirical studies in accounting and finance (e.g., Pinnuck and Lillis, 2007; Ellul et al., 2018; Benmelech et al., 2019), we use firms' net hiring (i.e., the percentage change in the number of employees) to proxy for their investment in labor. We measure investment inefficiencies as the absolute deviation of actual net hiring from its expected (optimal) level, predicted by economic fundamentals. Our measure thus captures firms' abnormal net hiring, that is, the amount of net hiring not attributable to those underlying economic factors. We note that our approach to measuring investment (in)efficiency is widely used in the capital investment literature (e.g., Richardson, 2006; Biddle et al., 2009; Cheng et al., 2013; García Lara et al., 2016; Stoughton et al., 2016). Importantly, our approach also follows recent papers that particularly focus on labor investment inefficiencies (Jung et al., 2014; Ben-Nasr and Alshwer, 2016).

For our main analysis, we rely on the labor demand model of Pinnuck and Lillis (2007) to estimate a firm's expected level of net hiring. Their model specification is similar to those used in several recent studies (e.g., Chodorow-Reich, 2014; Falato and Liang, 2016; Giroud 
and Mueller, 2017; Ellul et al., 2018; Benmelech et al., 2019) but has the advantage of using a more comprehensive list of firm-level variables to explain normal hiring practices. Nevertheless, in our robustness tests, we consider several modifications to this model, for instance, by controlling for factors related to the supply of labor and frictions in local labor markets that may affect firms' investment in employees. We further estimate expected net hiring using a firm's average investment in the previous three years (Titman et al., 2004; Cella, 2014) and median investment in the firm's industry (Harvey et al., 2004; Cella, 2014). Our findings are robust to the use of these alternative proxies and hence do not depend on the use of the Pinnuck and Lillis (2007) labor demand model.

To test our predictions, we use a sample of 51,414 firm-year observations from 1982 to 2015. We find strong evidence that the presence of institutional investors with longer investment horizons is associated with significantly lower inefficiencies in labor investments. In particular, the impact of investor portfolio stability on abnormal net hiring is economically significant: a one standard deviation increase in Investor_Stability (0.059), which corresponds to an increase in investment horizon of 6.6 months, is associated with a reduction in abnormal net hiring of $8.9 \%$ relative to the median. This result holds across a variety of model specifications, different measures of expected net hiring, and is robust to controlling for known factors that might affect the efficiency of employment decisions.

Next, we provide evidence on the interaction between Investor_Stability and different types of inefficiencies in labor investments. Specifically, we investigate over-investment (overhiring and under-firing) and under-investment (under-hiring and over-firing) problems and find that, except for over-firing, each form of inefficiency is mitigated by the presence of long-term investors. Moreover, we show that the impact of Investor_Stability on abnormal net hiring is more pronounced for firms that face higher labor adjustment costs (LACs). It is also stronger for firms with high LACs relative to capital adjustment costs (CACs) or those that attach more 
importance to their labor force. These findings are consistent with the notion that long-term investors play a stronger monitoring role when deviation from optimal labor demand is more costly to the firm or when human capital is more important to its business model.

We run further cross-sectional tests to study the types of firms that are more likely to engage in abnormal net hiring and thus require more monitoring by long-term investors. We contend that the monitoring role of long-term investors is most relevant for firms that have stronger incentives and/or greater opportunities to deviate from expected net hiring. In line with our predictions, we find that the role of long-term investors in reducing labor investment inefficiencies is more important for complex firms and firms with weak governance and/or low financial reporting quality. These firms have greater agency conflicts and information asymmetry, giving management more opportunities to deviate from optimal investment policy and hence requiring more attention from long-term investors. We also find the impact of Investor_Stability on labor investment inefficiency to be more pronounced for companies with shorter-maturity debt, male or older CEOs, and different levels of managerial ownership, which may arguably suffer from greater agency conflicts.

A major concern with a causal interpretation of our findings is self-selection. The coefficient on Investor_Stability may be biased if long-term investors select firms that are more efficient in their labor investments. Omitted variable bias poses yet another concern. A firm's ownership structure may be related to unobservable factors that also affect its labor investments, leading to a spurious correlation. We address those concerns in four ways. First, we mitigate the omitted variable bias by controlling for a host of corporate governance variables, other non-labor investments, and alternative explanations that may be related to investor horizons. Second, we perform propensity score matching (hereafter, PSM) to alleviate the possibility that our results are driven by observable confounding effects. The PSM analysis 
shows that, in line with our baseline finding, the abnormal net hiring of firms with high Investor_Stability is significantly lower than that of matched firms with low Investor_Stability.

Third, following Derrien et al. (2013) and Nguyen et al. (2020), we split long-term investors into non-indexers and indexers. Using Bushee's (1998) institutional investor classifications, we show that our results are similar for both (potentially endogenous) nonindexers and (reasonably exogenous) indexers. The latter are passive investors that are widely diversified and do not trade much; that is, they cannot freely discard firms' stocks as they must replicate an index. For this reason, they are more likely to influence the firms in which they invest through "voice". As Derrien et al. (2013) and Appel et al. (2016) describe, indexers cannot be active investors but have an incentive to be activist investors. The fact that our results hold for long-term indexers mitigates the potential concern that long-term investors self-select to invest in firms with more efficient investments in employees.

Fourth, and importantly, we adopt an instrumental variable (hereafter, IV) approach where we exploit the plausibly exogenous variation in the holdings of quasi-indexer investors as a result of the annual reconstitutions of the Russell 1000 and 2000 indexes. Following Schmidt and Fahlenbrach (2017), we track firms that switched from one index to the other in a particular year, focusing on changes in index assignment for firms ranked close to the Russell 1000/2000 threshold. Given that these indexes are value-weighted and quasi-indexer investors have to apply the index weights in their portfolios to mimic their benchmark index and minimize their tracking error, the (random) changes in index assignment for firms around the threshold lead to significant changes in quasi-indexer ownership levels. Using two-stage least squares (hereafter, 2SLS) estimations, we show that exogenous increases in long-term ownership are associated with reductions in labor investment inefficiency, which is consistent with our main finding. Taken together, while it is difficult to rule out endogeneity concerns, our tests consistently point to a causal effect of long-term ownership on labor investment 
efficiency. Still, we acknowledge that our study only provides indirect evidence on the channel driving this result, namely, monitoring by long-term institutional investors.

The main contribution of our study is that we document novel evidence of the role of institutional investors in mitigating incentive problems associated with labor investments. Recent evidence suggests that the presence of long-term investors can help reduce the agency conflicts associated with investments in capital (Cella, 2014), research and development (Bushee, 1998; Aghion et al., 2013; Harford et al., 2018), acquisitions (Gaspar et al., 2005; Chen et al., 2007), and corporate social responsibility (Neubaum and Zahra, 2006; Nguyen et al., 2020). However, existing results regarding the impact of investor horizons on firms' nonlabor investments cannot be generalized to an analysis of labor investments primarily due to differences in their adjustment costs. The classical view of labor typically considers it a variable production factor that has limited adjustment costs, which can be paid out from firm revenues (Dixit and Pindyck, 1994). The reason is that, relative to capital expenditures, the timing of labor investments better matches with that of current-year revenues, meaning that labor costs can be covered by operating cash flows (Jung et al., 2014; Khedmati et al., 2019). To the extent that labor is a variable production factor, it has limited market frictions and can be adjusted at a very low cost. Accordingly, one could argue that even when firms deviate from optimal net hiring, they can easily revert to the optimal level. In the absence of labor market frictions, labor adjustment requires little, if any, monitoring effort by long-term institutional investors. Combining this argument with our main hypothesis suggests that the question of whether longterm investors play a role in shaping firms' employment decisions is an empirical one.

Even in the presence of labor market frictions (e.g., Dube et al., 2010), ${ }^{4}$ the cost of adjusting labor appears to be lower than the cost of adjusting non-labor investment (e.g.,

\footnotetext{
${ }^{4}$ Labor has increasingly been subject to more (labor) market regulations, which increase the LACs (Matsa, 2018). Between the 1970s and 1990s, for instance, many states in the U.S. adopted WDLs to protect employees from
} 
Bloom, 2009). Since the magnitude of factor adjustment costs directly determines how firms make investment decisions, the effect of long-term institutional investors on labor investment should differ from that on capital investment. This effect could be more pronounced for labor investment if firms facing relatively higher CACs already maintain capital investment close to its optimal level and thus require relatively less monitoring for capital expenditure. However, when CACs are relatively higher than LACs, long-term investors may have a stronger incentive to monitor capital than labor investment because deviations from the optimal level of capital investment are relatively more costly to the firm. Our arguments are based on the premise that long-term institutional investors may have to carefully consider where to focus their monitoring effort, i.e., on labor or capital investments, since monitoring costs could be significant (Gaspar et al., 2005), and investors have finite monitoring resources. Overall, these arguments lead to alternative views and suggest that the effect of long-term institutional investors on corporate investment in employees is an open empirical question that warrants further research.

In sum, it is important to examine whether and to what extent long-term investors reduce inefficient investments in labor. Our study fills this gap in the literature by providing the first evidence that the presence of long-term investors is associated with improvements in corporate decisions relating to investments in labor. Our robustness checks also suggest that this effect is incremental to the impacts of investor horizons on other non-labor investments that may be correlated with investments in employees. As mentioned above, we further find that this effect is more pronounced for firms with higher LACs relative to CACs. This latter finding highlights the differences between labor and non-labor investments in terms of their adjustment costs, thus showing the importance of investigating the former type of investment.

wrongful termination practices. These frictions in the labor market could affect the impact of long-term ownership on abnormal net hiring, either by strengthening the incentives of long-term owners to monitor managerial actions or by reducing managers' incentives to deviate from optimal employment levels. 
We also contribute to a broader line of research that investigates the impact of investor horizons on corporate outcomes, including the cost of capital (Elyasiani et al., 2010; Attig et al., 2013, Huang and Petkevic, 2016), the potential for financial misreporting (Burns et al., 2010), the sensitivity of investment to internal cash flows (Attig et al., 2012), the tradeoff between dividends and share repurchases (Gaspar et al., 2013), seasoned equity offerings (Hao, 2014), and CEO turnover-performance sensitivity (Gao et al., 2017). ${ }^{5}$ In robustness checks, we show that our main finding holds after controlling for many of these factors.

Our study also relates to a growing body of literature on the interactions between labor and corporate policies in the presence of incentive problems and various governance mechanisms. As reviewed above, this literature has examined managers' downsizing decisions (Bertrand and Mullainathan, 2003; Perry and Shivdasani, 2005), their incentives to collude with workers for mutual protection (Pagano and Volpin, 2005; Atanassov and Kim, 2009), their preference for maintaining strong ties with employees, increasing worker wages, and avoiding lay-offs (Cronqvist et al., 2009; Landier et al., 2009), as well as their incentives to under-invest in labor (Graham et al., 2005). We show that the existence of institutional investors with longer investment horizons in a firm's ownership structure can mitigate the incentive problems associated with the firm's employment decisions.

Finally, our paper is closely related to three recent studies by Jung et al. (2014), BenNasr and Alshwer (2016), and Khedmati et al. (2019) that also consider the implications of agency conflicts for labor investments. However, the focus of those studies is different from ours, as they examine financial reporting quality, stock price informativeness, and absence of CEO-director ties. Our results suggest that investor horizons, as an external governance mechanism, can also help to reduce these inefficiencies.

\footnotetext{
${ }^{5}$ Our paper is also related to a broader literature examining other motives of institutional investors to engage in monitoring (e.g., Fich et al., 2015; Ward et al., 2018).
} 
The remainder of the paper is organized as follows. Section 2 describes the data and research design. Section 3 reports and discusses the main empirical results. Section 4 presents several robustness tests whereas Section 5 addresses endogeneity concerns. Section 6 examines the role of short-term investors, and Section 7 draws conclusions.

\section{Data and research design}

\subsection{Sample and data sources}

We begin with all firms in Compustat between 1982 and 2015. We then exclude firms with missing data for the main variables used in our regressions. Consistent with the extant literature, we exclude financial firms and utilities (SIC codes between 6,000 and 6,999 or 4,900 and 4,999). ${ }^{6}$ We obtain data on the portfolio holdings of institutional investors from the Thomson-Reuters Institutional Holdings (13F) database, which provides institutional common stock holdings and transactions, as reported on Form 13F that is filed with the SEC. This data set contains ownership information on common stock positions (of more than 10,000 shares or $\$ 200,000$ in value) by institutional managers with $\$ 100$ million or more in equity securities under discretionary management. Information on firms' net hiring and financial characteristics is obtained from Compustat. ${ }^{7}$ Data on stock returns come from the Center for Research in Security Prices (CRSP). To mitigate the effect of outliers, we winsorize all Compustat variables at the $1^{\text {st }}$ and $99^{\text {th }}$ percentiles of their distributions. The final sample consists of 51,414 firmyear observations representing 6,313 unique firms over the period 1982 to 2015.

\footnotetext{
${ }^{6}$ We exclude financial firms and utilities because these firms are heavily regulated, and their financing and investment policies may be quite different from those of other firms. For instance, prior studies argue that managers of regulated firms often have less discretion over future investment decisions than those of unregulated firms (e.g., Smith, 1986; Barclay and Smith, 1995).

7 The Compustat variable reporting the number of employees (emp) contains missing values due to the fact that firms may choose whether or not to report these data. Nevertheless, in our sample of Compustat firms matched with the Thomson-Reuters Institutional Holdings (13F) database, emp is available for almost $97 \%$ of the firmyear observations, indicating that sample selection is not a concern.
} 


\subsection{Investment horizon measures}

To measure the investment horizon of a firm's institutional investors based on the turnover rate, we proceed as follows. Using data on the portfolio holdings of institutional investors from the Thomson-Reuters Institutional Holdings (13F) database, and following the extant literature (Gaspar et al., 2005; Yan and Zhang, 2009; Cella et al., 2013; Huang and Petkevic, 2016, Hovakimian and $\mathrm{Hu}, 2016$ ), we compute each institutional shareholder's investment horizon by looking at the quarterly turnover level of their portfolio; that is, the ratio of dollar share purchases and sales during a quarter to the total dollar value of the portfolio. The logic behind this measure is that investors will be classified as long term if they churn their overall portfolio less frequently. Derrien et al. (2013) demonstrate the validity of the portfolio turnover measure as a proxy for the investment horizon by showing that the measure is persistent over time; that is, that the investor horizon is a characteristic of investors, and that the measure is accurate in classifying investors known to be long term, such as Warren Buffett (Berkshire Hathaway), CalPERS, and the Vanguard Group, and those known to be short term, such as György Soros (Soros Fund Management) and Stevie Cohen (SAC Capital Management). The turnover rate of institutional investor $i$ in quarter $q$ is calculated as follows:

$$
T R_{i, q}=\frac{\sum_{k=1}^{Q_{q}}\left|N_{k, i, q} P_{k, q}-N_{k, i, q-1} P_{k, q-1}-N_{k, i, q-1} \Delta P_{k, q}\right|}{\sum_{k=1}^{Q_{q}} \frac{N_{k, i, q} P_{k, q}+N_{k, i, q-1} P_{k, q-1}}{2}}
$$

where $T R_{i, q}$ is the turnover rate of investor $i$ in quarter $q, Q_{q}$ is the set of companies held by investor $i$ in quarter $q, N_{k, i, q}$ is the number of shares of company $k$ held by investor $i$ in quarter $q$, and $P_{k, q}$ is the share price of firm $k$ in quarter $q$. By construction, the range of the turnover rate is the interval $[0,2]$. To provide a more stable and accurate classification of an investor's horizon, we then calculate the average turnover level of his/her portfolio over the previous four quarters as follows: 


$$
A v g_{-} T R_{i, q}=\frac{1}{4} \sum_{r=1}^{4} T R_{i, q-r+1}
$$

Using the investor-level turnover rate $\left(A v g_{-} T R_{i, q}\right)$, we then calculate the firm-level turnover rate as the weighted average of the turnover rates of all institutional investors in a firm's ownership structure:

$$
\text { Inv_Turnover }_{k, q}=\sum_{i \in S_{k, q}} w_{k, i, q} A v g_{-} T R_{i, q}
$$

where $w_{k, i, q}$ is the weight of investor $i$ in the total percentage held by institutional investors in company $k$ at quarter $q$, and $S_{k, q}$ is the set of institutional investors in company $k$ at quarter $q$. Finally, to ensure that higher values of our horizon proxy correspond to a longer investment horizon and to simplify the interpretation of our results, we multiply the investor turnover measure by -1 . We use this proxy, which we call Investor_Stability, to study how the investment horizon of a firm's institutional shareholders affects the efficiency of its labor investments. In addition to this main proxy (Investor_Stability), in Section 5.2 we use alternative measures of long-term investor horizons based on Bushee's (1998, 2001) institutional investor classifications. ${ }^{8}$

\subsection{Measure of labor investment efficiency}

Following Pinnuck and Lillis (2007), Ellul et al. (2018), and Benmelech et al. (2019), we use firms' net hiring, measured as the percentage change in the number of employees between year $t-1$ and year $t$, to proxy for investment in employees. We then employ the standard approach in the capital and labor investment literatures (e.g., Richardson, 2006; Biddle et al., 2009; Cheng et al., 2013; Jung et al., 2014; Ben-Nasr and Alshwer, 2016; García Lara et al., 2016; Stoughton et al., 2016), and measure labor investment inefficiencies

\footnotetext{
${ }^{8}$ We thank Brian Bushee for sharing his institutional investor classification data on his personal website: http://acct.wharton.upenn.edu/faculty/bushee/IIclass.html.
} 
(Abnormal_Net_Hiring) as the absolute deviation of actual net hiring from its expected level predicted by economic fundamentals:

$$
\text { Abnormal_Net_Hiring }=\mid \text { Actual_Net_Hiring }- \text { Expected_Net_Hiring } \mid
$$

Our main approach to estimating a firm's expected level of net hiring is well-grounded in prior research in economics, accounting, and finance. In the labor economics literature, Hamermesh (1989) derives a simple model of long-run equilibrium labor demand, which maximizes firm value. ${ }^{9}$ Subsequent studies then employ a reduced-form labor demand model, often augmented by including a number of firm characteristics. We follow this strand of research and use the labor demand model of Pinnuck and Lillis (2007), which also resembles the employment models estimated in recent studies (e.g., Chodorow-Reich, 2014; Falato and Liang, 2016; Giroud and Mueller, 2017; Ellul et al., 2018). However, while the latter models typically include a limited number of explanatory variables, the Pinnuck and Lillis (2007) model uses an extensive list of firm-specific variables to explain normal hiring practices. Formally, the model takes the following form:

$$
\begin{aligned}
& \text { Net_Hiring }_{i, t}=\alpha+\beta_{1} \text { Sales_Growth }_{i, t}+\beta_{2} \text { Sales_Growth }_{i, t-1}+\beta_{3} \text { Profit }_{i, t}+\beta_{4} \Delta \text { Profit }_{i, t} \\
& +\beta_{5} \text { SProfit }{ }_{i, t-1}+\beta_{6} \text { Return }_{i, t}+\beta_{7} \text { Size }_{i, t-1}+\beta_{8} \text { Quick_Ratio }_{i, t-1} \\
& +\beta_{9} \Delta \text { Quick_Ratio } \text { Rat }_{i, 1}+\beta_{10} \Delta \text { Quick_Ratio }_{i, t}+\beta_{11} \text { Leverage }_{i, t-1} \\
& +\sum_{L=1}^{5} \delta_{L} \text { Loss }_{-} \text {Bins }_{t}{ }^{1 \text { to } 5}+\lambda_{j}+\varepsilon_{i, t}
\end{aligned}
$$

where the subscripts $i$ and $t$ refer to firm $i$ and year $t$, respectively. Net_Hiring is the percentage change in the number of employees, Sales_Growth is the percentage change in sales revenue, Profit is net income scaled by beginning-of-year total assets, $\Delta$ Profit represents the change in net income scaled by beginning-of-year total assets, Return is the total annual stock return, Size is measured as the natural logarithm of the firm's book value of assets, Quick_Ratio is the ratio

\footnotetext{
${ }^{9}$ See also Bond and Van Reenen (2007) for a comprehensive review of factor demand models.
} 
of cash and short-term investments plus receivables to current liabilities, Leverage is measured as long-term debt plus debt in current liabilities, scaled by the book value of assets, and Loss_Bins are five dummy variables indicating each interval of profitability of length 0.005 from 0 to -0.025 . For example, Loss_Binl takes the value of one if Profit is between -0.005 and 0 , and zero otherwise, and so on for the other Loss_Bins; see Appendix A for detailed variable definitions. The model also includes industry fixed effects $\left(\lambda_{j}\right)$ to control for unobserved industry characteristics affecting net hiring.

In Appendix B, we present the regression results for the labor demand model, Eq. (5). We find that sales growth, profitability, stock returns, size, and corporate liquidity have a positive and significant impact on net hiring. Leverage and the loss bins, on the other hand, are negatively associated with net hiring. These results are consistent with Pinnuck and Lillis (2007) and prior theoretical predictions, suggesting that the labor demand model is well

estimated. We note that the fitted value from the model is the estimate of a firm's Expected_Net_Hiring, while the absolute value of the unexplained portion (or residual) becomes our estimate of a firm's Abnormal_Net_Hiring. To confirm the validity of our measure of sub-optimal net hiring, we show in our Internet Appendix (Section 1 and Table IA.1) that this measure has a significant and negative impact on future firm market value and operating performance, which is consistent with our conjectures.

\subsection{Empirical specification and control variables}

To explore the interaction between institutional investment horizons and labor investment efficiency, we examine the effect of Investor_Stability on Abnormal_Net_Hiring. Specifically, we estimate the following baseline model:

$$
\text { Abnormal_Net_Hiring } g_{i, t}=\alpha+\delta \text { Investor_Stability }_{i, t-1}+\beta^{\prime} X_{i, t-1}+\lambda_{j}+\eta_{t}+\varepsilon_{i, t}(6)
$$

where Investor_Stability and Abnormal_Net_Hiring are defined as in Sections 2.2 and 2.3, respectively. The vector $X_{i, t-1}$ includes control variables that, based on previous literature (e.g., 
Jensen, 1986; Stulz, 1990; Richardson, 2006; Biddle et al., 2009), are likely to be associated with a firm's investment efficiency. In particular, as in Jung et al. (2014) and Ben-Nasr and Alshwer (2016) we control for investment opportunities, size, corporate liquidity, dividend payouts, cash flow and sales volatilities, tangibility, any incidence of losses, net hiring volatility, labor intensity, and institutional ownership. We also include a proxy for inefficiencies associated with non-labor investments (capital expenditure, R\&D expenditure, and acquisitions) to control for any indirect effect on Abnormal_Net_Hiring from other investment decisions. We further account for time-invariant industry heterogeneity and time trends by including a vector of industry fixed effects and time dummies $\left(\lambda_{j}\right.$ and $\left.\eta_{t}\right) .{ }^{10}$ Note that in our robustness tests (Section 4.3), we also control for a number of other variables. Appendix A provides detailed variable definitions.

\subsection{Summary statistics and univariate test}

Table 1 reports summary statistics for the labor investment, ownership, and control variables used in our main analysis. ${ }^{11}$ The average and median values of our dependent variable, Abnormal_Net_Hiring, are 0.123 and 0.070 , respectively; this means that actual net hiring deviates on average from expected net hiring by 12.3 percentage points. These figures are in line with Jung et al. (2014), who report mean and median Abnormal_Net_Hiring values of 0.113 and 0.070 , respectively. Institutional investors own, on average, $43.4 \%$ of firms'

\footnotetext{
${ }^{10}$ As mentioned in Section 2.2, investor horizon is a persistent investor characteristic. It follows that most of the investor horizon variation comes from the cross-section not the time-series. Hence, we refrain from including firm fixed effects because little is gained by focusing on limited within firm variation; this modelling choice is common in research using a similar investor horizon measure (Gaspar et al., 2005; Gaspar et al., 2013; Harford et al., 2018). In robustness tests, we control for unobservable heterogeneity using a series of state, industry, and year fixed effects as well as their interactions. We present a formal identification strategy in Section 5.

${ }^{11}$ The descriptive statistics for the variables in Eq. (5) are similar to those reported in prior studies. For example, the average expected annual percentage change in the number of employees (Expected_Net_Hiring) is 5\%, which is close to the 5.4\% reported in Pinnuck and Lillis (2007).
} 
equity. There is a clear time trend, with institutional ownership increasing substantially over the last 20 years (untabulated result). The average investor turnover (Inv_Turnover) is 0.191, which means that institutional investors hold an average stock in their portfolio for around 31.4 months. ${ }^{12}$ Dedicated institutional investors hold, on average, $5.5 \%$ of their portfolio firms' shares, as compared to the $30.3 \%$ held by quasi-indexer investors.

We next conduct a univariate analysis in which we compare Abnormal_Net_Hiring for firms with above- and below-median Investor_Stability (untabulated). Our comparison reveals that firms with above-median Investor_Stability display significantly lower Abnormal_Net_Hiring than firms with below-median Investor_Stability. Specifically, the average (median) value of Abnormal_Net_Hiring is $11.4 \%(6.6 \%)$ for firms with above-median Investor_Stability, compared to a value of $13.2 \%(7.4 \%)$ for firms with below-median Investor_Stability. The difference of $1.8(0.8)$ percentage points is statistically significant at the $1 \%$ level, and is economically significant as it amounts to around $15 \%(11 \%)$ of the average (median) value of Abnormal_Net_Hiring. This preliminary finding suggests that more stable ownership by institutional investors is associated with fewer sub-optimal employment decisions, consistent with our main hypothesis.

\section{Empirical results}

\subsection{Investment horizons and labor investment efficiency: Main findings}

Table 2 presents the regression results on the relation between long-term investors and abnormal net hiring. We report $t$-statistics based on heteroskedasticity-robust standard errors, clustered at the firm level. Models 1-3 include industry and year dummies. In Model 1, we

\footnotetext{
${ }^{12}$ Recalling that Inv_Turnover takes values in the interval [0, 2], an average Inv_Turnover of 0.191 means that $0.191 / 2=9.55 \%$ of the portfolio is turned over in a given quarter. This corresponds to $38.2 \%$ of the position being turned over in a given year, which implies that institutional investors hold an average stock in their portfolio for around $12 / 0.382=31.4$ months. There is a clear time trend in Inv_Turnover; that is, Inv_Turnover has increased in recent years (untabulated result).
} 
exclude Investor_Stability and regress Abnormal_Net_Hiring on the control variables. Firms with higher institutional ownership stakes, of a bigger size, with less liquidity, lower debt, positive dividend payouts, more tangible assets, and higher labor intensity tend to exhibit lower inefficiencies in their investments in employees. At the same time, Abnormal_Net_Hiring is positively related to a higher incidence of losses, abnormal non-labor investments, ${ }^{13}$ and the volatilities of cash flow, sales, and past net hiring. These results are broadly consistent with previous evidence in the literature (e.g., Jung et al., 2014; Ben-Nasr and Alshwer, 2016).

Model 2 is identical to Model 1 except that Investor_Stability, our main variable of interest, is introduced as an additional explanatory variable. In line with our main hypothesis, we find that the coefficient estimate for Investor_Stability is negative and highly significant, suggesting that a more stable institutional ownership structure helps improve the efficiency of a firm's labor investments. ${ }^{14}$ The impact of investor portfolio stability on abnormal net hiring is also economically significant: a one standard deviation increase in Investor_Stability (0.059), which corresponds to an increase in the investment horizon of 6.6 months, is associated with a reduction in Abnormal_Net_Hiring of $8.9 \%$ relative to the median. ${ }^{15}$

In the last two models, we evaluate the robustness of our results to controlling for other sources of unobserved heterogeneity. Model 3 repeats the analysis of Model 2 but also adds state-level fixed effects. Including state fixed effects allows us to account for persistent differences across states in characteristics that could affect the investment horizon and labor

\footnotetext{
13 Abnormal non-labor investment is the only variable in our model that is not lagged, and hence demonstrates significant explanatory power with a large $t$-statistic of about 27. Our results are robust to excluding this variable or taking its lagged value, in which case the $t$-statistic drops to approximately 12.

14 Since investor turnover and stability may be associated with firm-level volatility and uncertainty, in (untabulated) tests, we further control for stock return volatility, firm-level uncertainty (Alfaro et al., 2019), and firm-level political risk (Hassan et al., 2019). Our results remain unchanged.

15 We obtain qualitatively similar results if we instead define long-term ownership as the firm's percentage ownership held by investors in the bottom $33^{\text {rd }}$ percentile of the average turnover rate $\left(A v g \_T R_{i, q}\right)$.
} 
investment relation; for example, geographic differences, which affect the relocation decisions of highly educated populations (Moretti, 2011), or differences in labor laws such as WDLs that are time-invariant during our sample period and affect the labor demand function (e.g., Serfling, 2016). In Model 4, instead of controlling for industry, year, and state fixed effects separately like we do in Model 3, we include industry-year and state-year fixed effects to control for time-varying heterogeneity across industries and time-varying differences in local economic environments (Gormley and Matsa, 2014). The sign and magnitude of the coefficient on Investor_Stability in Models 3 and 4 is comparable to that of Model 2.

Overall, our findings are qualitatively similar across a variety of model specifications; that is, institutional ownership stability has a robust and negative impact on abnormal net hiring practices. ${ }^{16}$ This evidence is consistent with our main hypothesis that the investment horizon of a firm's institutional shareholders increases the efficiency of its labor investments.

\subsection{Investment horizons and specific types of labor investment inefficiency}

In this section, we provide evidence on the interaction between institutional investment horizons and specific forms of labor investment inefficiencies. Specifically, we investigate whether long-term institutional ownership mitigates over- and/or under-investment in labor. There is no a priori reason to anticipate an asymmetric effect on those two forms of investment inefficiencies. Hence, we expect the presence of long-term investors to be associated with lower inefficiencies in both over- and under-investment. We define over-investing firms as those with positive abnormal net hiring (i.e., Actual_Net_Hiring greater than Expected_Net_Hiring) and under-investing firms as those with negative abnormal net hiring (i.e., Actual_Net_Hiring less than Expected_Net_Hiring). We estimate Eq. (6) for these subsamples of over- and under-investing firms and report the results in Table 3.

\footnotetext{
${ }^{16}$ We note that across all specifications the adjusted $\mathrm{R}^{2}$ is at $15 \%$, which indicates a goodness-of-fit comparable to that reported by studies using similar specifications (e.g., Jung et al., 2014; Benmelech et al., 2015).
} 
Panel A of Table 3 presents the results on the relation between investor stability and over-investment. As in our baseline regressions in Table 2, we include the controls, year, and industry fixed effects. In Models 2, 4, and 6, we further control for state fixed effects. In Models 1-2, we find that Investor_Stability reduces Abnormal_Net_Hiring for over-investing firms. In Models 3-6, we further decompose over-investment into over-hiring and under-firing based on whether a firm's labor force is expected to grow or diminish according to economic fundamentals. Specifically, a firm over-hires (under-fires) if it over-invests when its expected level of net hiring is positive (negative). We find that each form of over-investment is mitigated by the presence of long-term investors.

In Panel B of Table 3, we report the results on the effect of investor stability on underinvestment. We use the same model specifications as in Panel A. In Models 1-2, we find that Investor_Stability reduces the deviation between actual and expected net hiring for underinvesting firms. In Models 3-6, we further break down under-investment into under-hiring and over-firing. A firm under-hires (over-fires) if it under-invests when its expected level of net hiring is positive (negative). We find that under-hiring is mitigated by the presence of longterm investors; however, in Models 5-6, the results for over-firing become insignificant. In summary, we find that most specific forms of labor investment inefficiency are mitigated by the presence of long-term investors.

\subsection{The role of labor and labor adjustment costs \\ 3.3.1 Labor adjustment costs}

To better explain the investor incentives for the observed negative relation between investor horizons and labor investment inefficiencies, we examine whether the impact of Investor_Stability on Abnormal_Net_Hiring varies with the level of LACs. Earlier studies document the presence of economically significant costs associated with firms' labor adjustments. These costs include the costs of firing (severance pay and lawsuits), searching 
(recruitment agency fees and advertising), selection and hiring (application screening and interviews), training, and costs due to productivity losses (peer and supervisor disruption). ${ }^{17}$

There are two alternative views regarding the impact of LACs on the relationship between investor horizons and labor investment efficiencies. First, since firms cannot adjust their labor demand in a costless way, they should keep labor turnover stable and minimize deviations from the optimal labor demand policy implied by economic fundamentals (Dixit, 1997). This view implies that long-term investors have a stronger incentive to monitor the employment activities of the firm when it faces higher LACs, because deviations from the optimal labor demand policy are more costly to the firm. Hence, the impact of investor stability on abnormal net hiring should be stronger for firms with high LACs than those with low LACs. An alternative argument is that firms faced with high LACs already have an incentive to reduce abnormal net hiring, in which case they would require less monitoring by long-term investors. This argument predicts that the effect of investor stability on abnormal net hiring is less pronounced for firms with high LACs than those with low LACs. We note, however, that this argument is based on a restrictive assumption that there is no agency conflict between management and shareholders. Under the more realistic assumption that incentive problems exist, the presence of high LACs, by itself, does not necessarily deter self-interested, utilitymaximizing managers from making inefficient labor investments.

To proxy for LACs, we use two recently proposed measures in the literature: (a) the state-level passage of WDLs and (b) firms' reliance on skilled labor. First, as in Serfling (2016), we exploit an exogenous variation in firing costs, a major component of LACs, following the

\footnotetext{
${ }^{17}$ Using survey data, the hiring costs per person are estimated at $\$ 2,000$ for blue collar and manual labor workers and \$7,000 for professional and managerial employees, in 2003 dollars (Dube et al., 2010).
} 
state-level recognition of WDLs since the 1970 s. ${ }^{18}$ We use WDL to measure the strength of WDLs in a state; WDL is constructed by summing three distinct dummy variables for each of the three WDLs exceptions. Second, since firms with a high share of skilled workers face higher LACs (Oi, 1962; Pfann and Palm, 1993; Mortensen and Pissarides, 1994; Hamermesh and Pfann, 1996; Dixit, 1997), we adopt labor skills as another measure of LACs. Specifically, we follow Belo et al. (2017) and Ghaly et al. (2017), and use Occupational Employment Statistics (OES) data from the Bureau of Labor Statistics and the U.S. Department of Labor's O*NET program classification of occupations according to skill level, to construct an industry-specific index, Labor_Skill, that proxies for the LACs faced by the average firm in that industry. ${ }^{19}$

Table 4 shows how the impact of firms' Investor_Stability on Abnormal_Net_Hiring varies, conditional on WDL and Labor_Skill. In Panel A, we partition our sample firms into those headquartered in states that have recognized all three WDLs exceptions (i.e., firms with a WDL score of 3 and thus higher LACs) and those headquartered in states that have not adopted any of the exceptions (i.e., firms with a WDL score of 0 and thus lower LACs). Models 1 and 2 report the results for the whole sample, whereas Models 3-4 and 5-6 show the results for firms with over- and under-investment problems. The results indicate that the impact of Investor_Stability on Abnormal_Net_Hiring is significant only for firms with higher LACs. In particular, for the whole sample, the coefficient on Investor_Stability is approximately four times bigger for firms with high LACs $(-0.248)$ than for firms with low LACs $(-0.060)$; the difference is statistically significant at the $1 \%$ level. Models 3-4 and 5-6 reveal broadly similar

\footnotetext{
${ }^{18}$ WDLs include three common-law exceptions to the employment-at-will doctrine, which make it more costly and difficult for firms to dismiss workers. These exceptions include the public policy exception, the implied contract exception, and the good faith exception. A state can choose to adopt none to all of these exceptions (see Autor et al. (2006) for a detailed description of these laws).

19 The O*NET occupational classifications are based on how much education, related work experience, and training an employee would need to perform a given job at a competent level.
} 
patterns when we examine the impact of Investor_Stability on over- and under-investment problems separately. In Panel B, we define firms in the top (bottom) $30^{\text {th }}$ percentile of Labor_Skill as high- (low-) skill firms, which face high (low) LACs. ${ }^{20}$ The results continue to show that the impact of Investor_Stability on Abnormal_Net_Hiring is significant only for high-LACs firms; the only exception is the result for under-investment in Models 5 and 6 , where the coefficients are insignificant for both subsamples. In sum, our findings are broadly consistent with the view that long-term investors play a stronger monitoring role when the deviation from the optimal labor demand policy is more costly to the firm.

\subsubsection{Labor and capital adjustment costs}

The previous analysis provides evidence of cross-sectional variation in the relation between long-term investors and labor investment efficiency conditional on firms' LACs. In this section, we further examine how this relation varies with the cost of adjusting labor investment relative to the cost of adjusting capital investment. A central objective of this analysis is to demonstrate that differences between labor and capital adjustment costs lead to differences in the magnitude of the impact of Investor_Stability on labor investment efficiency, thus showing that the findings of prior studies on non-labor investment do not readily apply to labor investments as well.

The economics literature reports that one of the most important differences between labor and non-labor investments lies in their cost of adjustment (Matsa, 2018). While the cost of adjusting labor could be substantial, it frequently appears to be lower than the cost of adjusting non-labor investment. For example, CACs, which include installation costs, losses due to disruptions to production, and particularly the irreversibility of capital investment (Dixit

\footnotetext{
${ }^{20}$ Our results are qualitatively similar when we define firms with above- (below-) median Labor_Skill scores as those with high and low LACs.
} 
and Pindyck, 1994), are also substantial, and are frequently larger in magnitude than LACs. ${ }^{21}$ We argue that the magnitude of adjustment costs directly affects how firms adjust their factor demand and reduce investment inefficiency. Since LACs are generally lower than CACs, the impact of long-term institutional investors on labor investment should differ from that on capital investment. The effect of investor horizons could be weaker for capital investment and more pronounced for labor investment if firms faced with relatively higher CACs already have stronger incentives to maintain capital investment close to what is optimal and thus require relatively less monitoring by long-term investors. However, when CACs are relatively higher than LACs, deviations from the optimal level of capital investment are relatively more costly to the firm, giving long-term investors a stronger incentive to monitor capital investment than labor investment; this would imply that the monitoring role of long-term investors is more pronounced for capital than labor investment. Overall, these arguments lead to two opposing predictions for the effect of investor horizons on labor investment efficiency.

The evidence presented in Section 3.3.1 indicates that long-horizon investors play a stronger role in monitoring corporate employment decisions in the presence of higher LACs, measured using the (state-level) passage of the WDLs or a labor skill index. This finding is consistent with the argument that in the presence of higher LACs, long-term investors exercise more monitoring to ensure that firms follow their optimal labor demand policy, thus avoiding high costs due to deviations from this policy. Using this line of reasoning, we thus predict that long-term investors have more incentive to monitor firms' labor investment decisions for firms

\footnotetext{
${ }^{21}$ Bloom (2009), for instance, examines the impact of uncertainty shocks and shows that, on average, the estimated component of CACs due to investment irreversibility is $34 \%$ of capital while the fixed component represents $1.5 \%$ of annual revenue. In terms of LACs, Bloom's estimates suggest that hiring and firing costs are about $1.8 \%$ of annual sales but the fixed cost component of LACs represents $2.1 \%$ of annual sales. See also previous estimates of LACs and CACs in Shapiro (1986), Hall (2004), and Merz and Yashiv (2007).
} 
with higher LACs-to-CACs ratios. We note that when the ratio of LACs to CACs is high, adjusting labor becomes relatively more important to firms than adjusting capital.

To test our prediction, in Table 5 we exploit the cross-sectional variation in LACs relative to CACs using proxies and estimates of those costs in recent research. In Panel A, we use firms' reliance on skilled labor to proxy for LACs, as in Section 3.3.1. We then use firms' asset redeployability to measure their CACs; this measure reflects the extent to which assets have alternative uses within and across industries (Kim and Kung, 2017; Campello et al., 2018). In Panel B of Table 5, we proxy for LACs and CACs using the industry estimates from Hall (2004); these estimates are based on the Euler equations for factor demand. We then estimate our model for firms with above- (below-) median LACs-to-CACs ratios. ${ }^{22}$

Panel A of Table 5 shows that the impact of long-term investors on labor investment inefficiency, and its two specific forms, over-investment and under-investment, is significant and negative, consistent with our baseline finding. Importantly, the impact of long-term investors is economically more pronounced when the LACs-to-CACs ratio is high; the only exception is the under-investment model where the effect is larger in magnitude for firms with high LACs-to-CACs ratios relative to firms with low LACs-to-CACs ratios but the difference in the coefficients on Investor_Stability is not significant. In Panel B of Table 5, we find that long-term investors have a significant and negative effect on labor investment inefficiency only for firms with high LACs relative to CACs. Tests on subsamples of over- or under-investing firms further confirm that this effect is only significant for firms operating in high LACs-toCACs industries. Overall, the results in Table 5 are consistent with the prediction that the impact of investor horizons on labor investment inefficiency is more pronounced for firms with

\footnotetext{
22 Pharmaceuticals, chemicals, business services, and wholesale trade are examples of industries with abovemedian LACs-to-CACs ratios. Petroleum and natural gas, primary metal, textiles, and construction materials are examples of industries with below-median LACs-to-CACs ratios.
} 
higher LACs relative to CACs. ${ }^{23}$ This finding once again underscores the role of factor adjustment costs and the differences between labor and capital, thus justifying the need for our empirical investigation of the effect of institutional investors' horizons on labor investment.

\subsubsection{The importance of human capital}

Our analysis has underscored the importance of institutional investor monitoring for firms facing greater LACs. However, long-term institutions may also have strong incentives to monitor employment decisions when labor is important to the firm's business model, not necessarily when LACs are high. In order to examine this conjecture, we split our cross section based on the importance of human capital to a firm. Recent research suggests that firms relying more on human capital, particularly skilled workers, tend to have substantial R\&D investments and intangible assets, including human and organizational capital (e.g., Falato et al. 2018; Klasa et al. 2018). Hence, we proxy for human capital importance using R\&D and intangible capital intensity. $R \& D$ intensity is measured as the ratio of $R \& D$ expenditure to total assets. We consider firms with above- (below-) median R\&D intensity as placing more (less) importance on human capital. To capture intangible capital intensity, we follow Peters and Taylor (2017) and define intangible capital as the sum of internally created and externally purchased intangible capital. Each year, we define firms with above- (below-) median intangible capital to total assets as high (low)-intangible capital-intensive and expect them to place greater (less) importance to human capital.

Panels A and B of Table 6 present the results using R\&D intensity and intangible capital intensity as proxies for human capital importance, respectively. Throughout all models in both

\footnotetext{
${ }^{23}$ In untabulated tests, we corroborate our evidence on the trade-off argument by performing an additional analysis in which we study how the relationship between long-term investors and firms' capital investment is affected by the magnitude of LACs relative to CACs. Consistent with our argument, we find that the role of long-term investors in mitigating capital investment inefficiencies is more pronounced with higher CACs-to-LACs ratios.
} 
panels the relation between Investor Stability and Abnormal Net Hiring is greater in magnitude and more statistically significant for firms that place more importance on human capital than those that place less importance on human capital, with the differences in the Investor Stability coefficients between the two subsamples of firms being statistically significant. This finding is consistent with the prediction that long-term institutional investor monitoring is more stringent when human capital is more important to the firm.

\subsection{Further cross-sectional analysis}

To shed more light on the types of firms that are prone to abnormal net hiring and thus require more monitoring by long-term institutional investors, we run additional cross-sectional tests. We argue that the monitoring role of long-term investors is most pertinent for firms that have stronger incentives and/or more opportunities to deviate from expected net hiring through earnings management and/or empire building. Hence, we examine how the relation between long-term institutional ownership and labor investment efficiency varies with firm complexity, corporate governance, financial reporting quality, debt maturity, CEO gender and age as well as managerial ownership. First, while complex firms, such as those operating in multiple business segments, may enjoy certain benefits of diversification (e.g., the internal capital market and co-insurance effect), they face greater agency conflicts and information asymmetries (e.g., Denis et al., 1997; Hoechle et al., 2012). As a result, diversified firms tend to take suboptimal investment decisions, for instance, via earnings management (Lim et al., 2008) and empire building (e.g., Jensen, 1986; Stulz, 1990). To alleviate those incentive problems, long-term institutional investors are likely to pay more attention to complex firms. In a similar vein, firms with weak governance and low financial reporting quality have greater agency problems, operate under greater information asymmetry, and hence provide more opportunities to deviate from optimal investment policy (Jung et al., 2014). Therefore, we also expect these firms to be monitored more closely by long-term investors. Based on these 
arguments, we expect the impact of Investor_Stability on under-investment and overinvestment in labor to be more pronounced for firms with a higher degree of firm complexity, lower quality of corporate governance, and lower quality of financial reporting.

Our predictions for the role of the other conditioning variables used in this analysis are more nuanced. Prior research shows that short-term debt acts as an effective external monitoring mechanism that helps discipline firm management (Myers, 1977; Gul and Goodwin, 2010) and alleviate incentive problems, including both underinvestment (Myers, 1977) and overinvestment (e.g., Huang et al., 2018). This view indicates that the impact of long-term investors on both over- and under-investment should be weaker (stronger) for firms with shorter (longer)-maturity debt. On the other hand, since short-term debt is associated with higher liquidity risk and greater lender enforcement, it may encourage borrowers to engage in earnings management (Fung and Goodwin, 2013), particularly to delay the arrival of bad news (Gupta et al., 2008). This view suggests that the impact of investor horizons on labor underinvestment may be more pronounced for firms with more short-term debt.

Recent research argues that because female directors/executives are more ethical and risk-averse, firms with female directors/executives follow conservative earnings management strategies (Sun et al., 2011) and exhibit high earnings quality (Srinidhi et al., 2011). There is also evidence that, as a result of overconfidence, male executives engage in more acquisitions, including negative NPV deals, than their female counterparts (Huang and Kisgen, 2013). Accordingly, we predict that the impact of long-term institutional investors on both under- and over-investment in labor is more (less) pronounced for firms with male (female) CEOs.

Furthermore, existing studies document mixed evidence on the role of CEO age in determining managerial incentives to manage earnings and empire build. Due to compensation incentives, young CEOs are likely to be associated with lower financial reporting quality (Huang et al., 2012) and greater bad-news-hoarding behavior (Andreou et al., 2017), while they 
also tend to pursue more acquisitions (Yim, 2013). However, old CEOs, especially those in the later stages of their careers, may have incentives to cut R\&D expenses (Dechow and Sloan, 1991) and engage in more earnings management (Demers and Wang, 2010) to boost short-term performance and post-retirement market value. In addition, due to career concerns, young CEOs may avoid mergers and acquisitions as they are more likely to be fired for poor performance (Chevalier and Ellison, 1999), while, due to retirement preferences, old CEOs, especially those of target firms, are more likely to engage in merger activity (Jenter and Lewellen, 2015). Given the conflicting arguments and evidence, how CEO age affects the link between long-term investors and labor investment inefficiency is an empirical question.

Finally, managerial ownership is associated with different incentives for managers to deviate from optimal net hiring. The traditional view argues that greater managerial ownership mitigates agency conflicts between managers and shareholders and thus reduces earnings management (Warfield et al., 1995) and accounting conservatism (LaFond and Roychowhury, 2008). Managers with more equity stakes in the firm are also less likely to diversify (Denis et al., 1997) and overinvest (Cook and Luo, 2018) while, consistent with managerial risk aversion, they may be more likely to "play it safe" (Gormley and Matsa, 2016). However, the competing argument suggests that, due to incentives to sell shares in the future, managers with greater stock ownership are more likely to manage earnings (Cheng and Warfield, 2005). These managers are also more likely to become entrenched and thus have an incentive to pursue value-destroying decisions (Narayanan, 1996; Eisdorfer et al., 2013). Again, given the mixed evidence in the literature, the question of how managerial ownership influences the association between investor horizons and labor investment inefficiency is an empirical one.

To test the above conjectures, we first run regressions for subsamples of firms with high and low firm complexity. We define a firm with a high (low) degree of complexity as one that has more (less) than two business segments (Ashbaugh-Skaife et al., 2008; Balakrishnan et al., 
2018; Abernethy et al., 2019). We then examine firms with high and low quality of governance; to measure corporate governance quality, we use the Cain et al. (2017) takeover index. We consider firms with above- (below-) median takeover index scores to be those with high (low) governance quality. Next, we study firms with high and low degrees of financial reporting quality. Using a measure of accounting quality based on discretionary accruals (e.g., Dechow and Dichev, 2002; McNichols, 2002), we define firms with above- (below-) median accounting quality as high (low) reporting quality firms. We then consider the impact of debt maturity by splitting our cross section into firms with below- and above-median short-term debt. We also partition our sample into firms run by male vs. female CEOs and old (above-median age) vs. young (below-median age) CEOs. Finally, we report the results separately for high (abovemedian) and low (below-median) managerial ownership firms. Managerial ownership is defined as the value of the CEO's stock and option portfolio based on Daniel et al. (2019).

Panels A and B of Table 7 report the results for under-investment and over-investment in labor, respectively. The results in Panel A show that the coefficient on Investor_Stability is only significant and negative in Models $1,4,6,8,11$, and 14 that is, when firms have a higher degree of firm complexity, lower quality of corporate governance, lower quality of financial reporting, more short-term debt, older CEOs, and lower managerial ownership. The $F$-test results further confirm that the effect of Investor_Stability on labor under-investment is economically stronger for those firms than for firms with the opposite characteristics. The results in Panel B on over-investment are qualitatively similar. The effect of Investor_Stability on over-investment in labor is more pronounced for more complex firms (Models 1 and 2), those with lower financial reporting quality (Models 5 and 6), those with male CEOs (Models 9 and 10), and those with higher managerial ownership (Models 13 and 14). In Models 3 and 4, the impact of long-term investors on labor over-investment is larger for weakly-governed firms than strongly-governed ones, although the difference is not significant. Similarly, in 
Models 7 and 8 (11 and 12) we document a more pronounced impact for firms with more longmaturity debt (older CEOs) but the differences in coefficients are not significant. Overall, the results are broadly consistent with our conjecture that the effect of long-term investors on labor investment inefficiency is stronger among firms that have stronger incentives and/or more opportunities to deviate from expected net hiring.

\section{Robustness tests}

\subsection{Alternative proxies and models for expected and abnormal net hiring}

A central issue in our research design is how we estimate a firm's expected (optimal) level of investment in employees. To examine the robustness of our results, we next replicate our analysis using several alternative measures of expected net hiring. In Panel A of Table 8, we estimate augmented models of expected net hiring. Since the original Pinnuck and Lillis (2007) model includes only industry fixed effects, in Models $1-3$, we include additional fixed effects. We control for industry and year fixed effects in Model 1, and then firm and year fixed effects in Model 2. In Model 3, we include firm, industry-year, and state-year fixed effects; the latter fixed effects capture time varying state characteristics (e.g., geographic location and local economic conditions) that could affect the supply of labor to the local labor market. In Model 4, we estimate an augmented Pinnuck and Lillis (2007) model controlling for year, firm, and state fixed effects, as well as eight additional controls that may affect firms' investment in labor and correlate with long-term institutional ownership, namely (a) capital expenditures; (b) R\&D expenditures; (c) acquisitions; (d) total institutional ownership; (e) payout ratio; (f) corporate governance quality; (g) WDL, that is, the time-variant state-level recognition of wrongful discharge laws (Serfling, 2016); and (h) future industry sales growth, which captures the forward-looking prospects of the industry where a firm operates. To ensure that Model 4 is as comprehensive as possible, we include both lagged and contemporaneous values of the controls. In Model 5, we interact all the covariates in the original Pinnuck and Lillis (2007) 
model with institutional ownership; this specification addresses the concern that the impact of the determinants of labor investment on expected net hiring is conditional on institutional ownership. In Model 6, we apply the methodology proposed by Chen et al. (2018) to deal with potential bias in the two-stage estimation procedure where the first-stage residual is used as the dependent variable in the second-stage regression. Specifically, we include all the covariates from the first-stage estimation of the Pinnuck and Lillis (2007) model in our second stage. The results across all models of Panel A are qualitatively similar to our baseline findings.

We next address the possibility that the distribution of Abnormal Net Hiring may differ for firms with different (high vs. low) levels of LACs since these costs may make optimal net hiring respond to economic fundamentals in an asymmetric fashion. To account for this, we first run the Pinnuck and Lillis (2007) labor demand model separately for firms facing low and high LACs to allow for differences in the effects of the independent variables on Net hiring. As before, we proxy for LACs using the firms' reliance on skilled labor (Labor_Skill), our preferred measure of LACs that captures both the costs of hiring and firing. For each year, we define firms in the top (bottom) 30th percentile of Labor_Skill as high (low) LACs firms. As expected, we document significant systematic differences in the coefficients on some economic fundamentals and the distribution of Abnormal Net Hiring for firms facing low and high LACs. Importantly, we next re-run our main analysis using the estimates for Abnormal Net Hiring calculated separately for low and high LACs firms. The results reported in Panel B of Table 8 suggest that the negative effect of Investor Stability on Abnormal Net Hiring remains significant for the whole sample as well as the over- and under-investment subsamples, although it is more pronounced when Abnormal Net Hiring is estimated separately for firms facing high LACs.

In Panel C of Table 8, we consider alternative definitions of optimal net hiring that are not based on any labor demand regression model. In Model 1, we estimate expected net hiring 
using the median investment in the firm's industry (Harvey et al., 2004; Cella, 2014), defining industries using the Fama-French (1997) 48-industry classification. In Model 2, we estimate expected net hiring using the firm's average investment in the previous three years (Titman et al., 2004; Cella, 2014). In both models, the coefficient on Investor_Stability remains negative and highly significant, suggesting that our results are robust to alternative definitions of expected net hiring that do not depend on the Pinnuck and Lillis (2007) model or its variants. ${ }^{24}$

\subsection{Controlling for other types of investments}

Investments in labor may be correlated with other forms of investments, such as capital expenditures, $R \& D$ expenses, and acquisitions. Thus, a concern with our finding regarding the relation between investor horizons and labor investment inefficiencies is that it could be primarily driven by contemporaneous non-labor investments. Although in our regressions we already include Abn_Non-labor_Invest to control for non-labor investment inefficiencies, we follow prior research (Jung et al., 2014) and perform two tests to mitigate the effects of those investments. First, we examine scenarios in which investments in employees (net hiring) are positively or negatively related to capital expenditures, R\&D expenditures, and acquisition expenditures; that is, when an increase in net hiring is associated with an increase or decrease in the other forms of investment. For each type of non-labor investment, we also study subsamples of firms that make investments in labor but report zero or missing values for the type of non-labor investment in question. Second, to further control for capital-labor complementarity, we examine subsamples of industries in which the elasticity of substitution between capital and labor is either above or below unity. The results, reported in our Internet

\footnotetext{
${ }^{24}$ In unreported tests, we find that the coefficient on Investor_Stability is only significant for firms that experience substantial Abnormal_Net_Hiring and/or consistently deviate from expected net hiring. These results are in line with the premise that long-term investors reduce inefficient investment in labor when it is significant and persistent, and thus likely to be intentional.
} 
Appendix (Section 2 and Table IA.2), show that the coefficient on Investor_Stability is significant and negative not only for the subsamples of firms in which labor and non-labor investments move in the same direction and likely act as complements, but also for the other subsamples. This suggests that our main finding is not simply driven by the relation between long-term ownership and non-labor investments.

\subsection{Controlling for alternative explanations}

Even though we formally address endogeneity concerns in Section 5, in what follows we carry out a number of tests to control for potential omitted variables or alternative explanations that may drive our results. First, a concern with our analysis is that our findings could be driven by omitted governance variables rather than monitoring by long-term investors. This explanation is based on the view that long-term ownership is associated with good governance practices (e.g., Appel et al., 2016), which are correlated with firms' investment in employees. To address this concern, we follow recent studies (e.g., Bhagat and Bolton, 2013; Cain et al., 2017) and control for a firm's governance by including seven variables in our regressions: (a) the Gompers et al. (2003) corporate governance index (G-index); (b) the Bebchuck et al. (2009) entrenchment index (E-index); (c) the Cain et al. (2017) takeover index (Takeover index); (d) the natural logarithm of the dollar value of common stock owned by the median director sitting on the board (Direct_Own); (e) the percentage of board members classified as independent (Ind_Direct); (f) Duality, which is an indicator variable that takes the value of one if the CEO of the sample firm is also the board chair, and zero otherwise; and $(\mathrm{g})$ Blockholdings, defined as the number of investors that own at least $5 \%$ of a firm's shares, ${ }^{25}$ which helps alleviate the concern that our findings could be primarily driven by investors' ownership concentration rather than by investor horizons.

\footnotetext{
${ }^{25}$ Our result is robust to alternative measures of blockholdings, such as the total ownership of blockholders, total ownership of the five largest institutions, ownership of the largest institution, or ownership concentration.
} 
The results reported in Models 1-7 of Panel A in Table 9 show that the impact of Investor_Stability on Abnormal_Net_Hiring is unaffected when we separately control for different measures of corporate governance. ${ }^{26}$ In Model 8 of Panel A, we find that our result also survives the inclusion of those additional controls all together. In all models the coefficient estimate for Investor_Stability remains negative and highly significant. ${ }^{27}$ Overall, these results mitigate the concern that our findings may be driven by the correlation between firms' longterm ownership and the quality of their governance practices.

Another concern with our analysis is that institutional holdings are associated with several corporate outcomes that may be correlated with Abnormal_Net_Hiring. Since longterm investors can affect firms' investment in capital (Cella, 2014), R\&D (Bushee, 1998; Aghion et al., 2013; Harford et al., 2018), acquisitions (Gaspar et al., 2005; Chen et al., 2007), and stakeholder capital (Neubaum and Zahra, 2006; Rubio and Vazquez, 2016, Nguyen et al., 2020), which are potentially related to labor investments, our inferences could be affected by those non-labor investments. Our results could also be driven by financial reporting quality because high-quality financial reporting, which is associated with long-term ownership (Burns et al., 2010), helps reduce information asymmetry between insiders and outsiders, thus leading to more efficient investments (Biddle and Hilary, 2006; Biddle et al., 2009), including investments in labor (Jung et al., 2014). Meanwhile, our findings may be due to managerial ability as long-term shareholders may invest in companies that happen to have more efficient

\footnotetext{
${ }^{26}$ In untabulated tests, we find that the additional results reported in Tables 3 and 4 also remain qualitatively unchanged after controlling for the governance characteristics. However, we refrain from using the specification with the governance variables throughout the analysis given the significant reduction in the number of observations due to missing governance data.

${ }^{27}$ Following Chen et al. (2007) and Fich et al. (2015), we also conduct a two-step analysis (untabulated), where in the first step we regress Investor_Stability on firm size, lagged stock return, leverage, Tobin's Q, and the $G$ index. We then use the residual from the above regression as the abnormal level of Investor_Stability; this measure captures the investment horizon of the firm's institutional investors that is unexplained by the governance of the firm. Our results remain qualitatively unchanged.
} 
labor investments simply because they have more able managers. Additionally, since investment in labor is costly, it is affected by firms' cost of capital, degree of financial constraints, and ability to access capital markets (Benmelech et al., 2015), which are also associated with long-term institutional ownership (e.g., Elyasiani et al., 2010; Attig et al., 2012; Attig et al., 2013, Hao, 2014; Huang and Petkevic, 2016). This argument implies that our results could be driven by those factors.

To rule out all these alternative explanations, in Panel B of Table 9, we control for (a) non-labor investments, namely, capital expenditures, R\&D expenditures, and acquisitions; (b) financial reporting quality (Dechow and Dichev, 2002; McNichols 2002); (c) managerial ability, proxied by managers' efficiency, relative to their industry peers, in transforming corporate resources into revenues, including their ability to manage employees more efficiently (Demerjian et al., 2012); ${ }^{28}$ (d) the implied cost of capital (e.g., Lau et al., 2010); (e) the degree of financial constraints, measured using the Kaplan and Zingales (1997) index; ${ }^{29}$ (f) corporate social responsibility, measured using KLD data (Nguyen et al., 2020); and (g) equity issues.

Models 1-7 of Panel B, Table 9, show that controlling for the above additional variables does not affect the statistical and economic significance of the Investor_Stability coefficient. Since those models only include the controls separately, in the remainder of Panel B, Table 9, we consider two comprehensive models that include those variables all together (Model 8), as well as the governance measures used in Panel A (Model 9). We find that the coefficient on Investor_Stability remains significantly negative in both models (albeit at the $10 \%$ in Model 9

\footnotetext{
${ }^{28}$ Demerjian et al. (2012) use data envelopment analysis to estimate firm efficiency. They then remove from the total firm efficiency measure any firm-specific characteristics that are expected to assist or hamper the management's efforts. The unexplained portion of firm efficiency is attributed to management ability.

${ }^{29} \mathrm{We}$ note that the results are robust to other conventional measures of financial constraints (e.g., Whited and $\mathrm{Wu}$, 2006; Hadlock and Pierce, 2010). They also remain qualitatively unchanged when we proxy for financial constraints using firms' investment-cash flow sensitivities (Fazzari et al., 1988).
} 
due to the small number of observations used). In sum, the results from Table 9 give us some confidence that our results are unlikely to be driven by alternative explanations.

\section{Addressing endogeneity concerns}

Although we have alleviated the omitted-variable bias by controlling for many timeinvariant and time varying effects, concerns remain over the causal interpretation of our empirical results because of the potential self-selection in long-term investors' investment decisions and the role of reverse causality inferences. In this section, we present three additional analyses to further alleviate concerns about self-selection and endogeneity in general. First, we perform PSM to further reduce the impact of omitted (observable) variables on our results. Second, we split long-term ownership into indexer and non-indexer ownership, which helps us deal with the self-selection problem. Third, and most importantly, we run IV/2SLS regressions that take advantage of plausibly exogenous changes in ownership by quasi-indexer investors as a result of the annual Russell indexes reconstitutions.

\subsection{Propensity score matching}

Since the characteristics of firms with high Investor_Stability may differ from those with low Investor_Stability, we use PSM to control for observable differences in firm and industry attributes among the two groups of firms. We match firms with above-median Investor_Stability with those with below-median Investor_Stability on year, industry (FamaFrench 48-industry classification), and all the control variables from our baseline regression. By matching on industry, we also remove unobserved industry heterogeneity that may be correlated with Investor_Stability. The results, reported in our Internet Appendix (Section 3 and Table IA.3), show that the abnormal net hiring of firms with high investor portfolio stability is significantly lower than that of propensity score matched firms with low investor portfolio stability, consistent with our main finding. 


\subsection{Indexer versus non-indexer long-term investors}

Following Derrien et al. (2013) and Nguyen et al. (2020), we use long-term indexers to mitigate the impact of self-selection. Using indexers is appropriate for our analysis for two main reasons. First, long-term indexers are passive investors that are widely diversified and do not trade much. They cannot choose their portfolio firms based on the firms' labor investment efficiency because they must replicate an index; their incentive is to minimize the tracking error relative to their benchmark index. Therefore, long-term indexers are plausibly exogenous; that is, they are not affected by self-selection. Second, index funds do not have the flexibility to sell their holdings of stocks. As a result of this inability to follow the "Wall Street Rule", they are more likely to try to influence the firms in which they invest through "voice" or private negotiations (Carleton et al., 1998; Del Guercio and Hawkins, 1999; Becht et al., 2009; Fenn and Robinson, 2009). As Derrien et al. (2013) and Nguyen et al. (2020) argue, indexers cannot be active investors, but they can play an activist role.

To examine the effect of long-term indexers on abnormal net hiring, we use Bushee's (1998) classifications of institutional investors: transient, dedicated, and quasi-indexer. We focus on the shareholdings by dedicated and quasi-indexer investors in each firm, who by definition are likely to be long-term investors. The results, reported in our Internet Appendix (Section 4 and Table IA.4), indicate that both types of long-term institutional ownership are negatively associated with abnormal net hiring. Overall, by showing that our results hold for reasonably exogenous long-term indexers, we can largely mitigate the concern that our inferences may be driven by self-selection.

\subsection{Russell indexes' reconstitutions}

In this analysis, we follow recent studies (e.g., Appel et al., 2016, 2019; Crane et al., 2016; Schmidt and Fahlenbrach, 2017) and use the annual reconstitutions of the Russell 1000 and 2000 indexes as a source of exogenous variation to the ownership by long-term indexer 
investors to identify its impact on labor investment efficiency..$^{30}$ The Russell 1000 (2000) index includes the 1000 (1001-3000) largest US listed firms by market capitalization. Both indexes are value weighted and exhibit highly significant differences in weights between firms at the top and bottom of each index (Appel et al., 2016). Indexer investors that track these indexes have strong incentives to apply similar weights to their index-mimicking portfolios since they wish to minimize their tracking error. Thus, indexers are expected to hold relatively large (small) equity positions in firms ranked at the top (bottom) of each index.

FTSE Russell reconstitutes the indexes on an annual cycle (every June) using firms' end-of-May market capitalizations. Following Schmidt and Fahlenbrach (2017), we focus on firms that switch from one index to the other as a result of these reconstitutions, since they are bound to experience significant changes in long-term indexer investment. This is particularly true for firms that are close to the Russell 1000/2000 threshold; that is, they were at the bottom of 1000 but moved to the top of 2000, or vice versa. These switches around the threshold should lead to exogenous changes in long-term indexer ownership since we can safely assume that index assignment around the threshold is random (Appel et al., 2016; Schmidt and Fahlenbrach, 2017). In other words, managers cannot take decisions that affect market capitalization in a way that will accurately predict index assignment so close to the threshold.

Following the arguments presented in Section 5.2, we expect a significant increase in long-term indexer holdings to lead to a reduction in labor investment inefficiency. To test this

\footnotetext{
${ }^{30}$ We note that long-term dedicated investors may have stronger incentives to monitor than long-term indexers. However, our analysis aims to further alleviate endogeneity concerns and the literature has been unable to identify any shocks that would lead to exogenous changes in long-term dedicated ownership. Hence, we focus on longterm passive investors; our setting exploits an exogenous variation in these investors' ownership and, to the extent that they also play a monitoring role, as argued in Section 5.2, our test provides indirect inference about the monitoring channel. Furthermore, it would have been preferable to use Investor_Stability as in our earlier tests. However, Investor_Stability captures the investment horizon of the average institutional investor with positive shareholdings in a firm, which by construction is bound to be less sensitive to an event that leads to changes in the investment levels of only one type of institutional investors, that is, indexers.
} 
prediction, we follow recent research (e.g., Schmidt and Fahlenbrach, 2017) and run 2SLS estimations; see our Internet Appendix (Section 5) for additional evidence justifying our estimation approach and a detailed discussion of why it is inappropriate to adopt a regression discontinuity design. As in Schmidt and Fahlenbrach (2017), we use three instrumental variables: the first two are indicator variables equal to one if a stock switches from the Russell 1000 index to the Russell 2000 index $\left(R 1000_{t-1} \rightarrow R 200{ }_{t}\right)$ or the Russell 2000 index to the Russell 1000 index $\left(R 2000_{t-1} \rightarrow R 100 t_{t}\right)$ at the annual Russell index reconstitution. The third instrument tracks the change in index rank from one year to another $\left(\operatorname{Rank}_{t}-\operatorname{Rank}_{t-1}\right)$ based on end-of-May market capitalization. The first-stage dependent variable is the annual change in quasi-indexer ownership (AQuasi-indexer Ownership) measured at the end of the first quarter following the reconstitution, whereas the annual change in abnormal net hiring (4Abnormal_Net_Hiring) becomes the second-stage dependent variable. ${ }^{31}$ We note that all results are estimated using ranks implied by firms' end-of-May CRSP market capitalization.

Table 10 reports the results from these 2SLS regressions. We consider two model specifications. In Panel A, we include the same set of controls as in Schmidt and Fahlenbrach (2017). In Panel B, we further add the controls from our baseline specification (Eq. (6)) and the float adjusted market cap (Appel et al., 2016; Crane et al., 2016). In both panels, we focus on switches that are close to the threshold (i.e., those switches resulting from small changes in market capitalization). Specifically, we examine two subsamples of firms that switched by at most 200 and 100 ranks between the two Russell indexes. We do not study all switchers

\footnotetext{
${ }^{31}$ Our sample consists of the Russell 1000 and Russell 2000 index constituents during the 1991-2006 period. Similar to Appel et al. (2016) and Crane et al. (2016), our sample period ends in 2006. This is because Russell modified its indexing methodology in 2007 by introducing a "banding" policy, which allows firms that should otherwise switch indexes to remain within their index if their market capitalizations did not deviate much from the threshold. This banding policy could potentially affect the local continuity of firm assignment around the threshold and would likely violate the exclusion restriction because the assignment of firms into the indexes is no longer affected only by market capitalization rankings.
} 
because switches far from the threshold may happen as a result of large changes in market capitalization, which could in turn be related to unobservable changes in firms' characteristics. This means that the index switch may affect labor investment efficiency not only through its impact on long-term ownership, which could violate the exclusion restriction.

In Panel A of Table 10, the first-stage regression results suggest that for both samples of switchers, the coefficients on the instruments are highly significant and with the anticipated sign. In particular, the coefficient on $R 1000_{t-1} \rightarrow R 200{ }_{t}\left(R 200{ }_{t-1} \rightarrow R 100{ }_{t}\right)$ is positive (negative) and highly significant, consistent with the prediction that Quasi-indexer Ownership increases (decreases) as firms move from the bottom of the Russell 1000 index to the top of the Russell 2000 index (the top of the Russell 2000 index to the bottom of the Russell 1000 index). The coefficient on $\operatorname{Rank}_{t}-\operatorname{Rank}_{t-1}$ is negative and significant, which is expected given that as firms move to higher ranks (i.e., when the variable takes negative values), the index weights become larger, and therefore indexer investors increase their holdings. Diagnostic tests (i.e., the $F$ - and $J$-tests) both suggest that these instruments are valid. Importantly, the secondstage results show that the coefficient on the fitted $\Delta$ Quasi-indexer Ownership is negative and highly significant, consistent with the prediction that increases in long-term ownership lead to reductions in labor investment inefficiency.

Panel B of Table 10 shows that the results are robust to including the original controls used in our baseline analysis and the float adjustment market cap. Specifically, in the first-stage regressions, the coefficients on the three instruments $R 1000_{t-1} \rightarrow R 2000_{t}, R 2000_{t-1} \rightarrow R 1000$ $t$, and Rank $_{t}-$ Rank $_{t-1}$ remain significant with the expected signs. Diagnostic tests are also satisfactory. Moreover, in the second-stage regressions, 4 Quasi-indexer Ownership continues to have a negative and significant impact on $\triangle A$ Abnormal_Net_Hiring. The magnitude of the effect appears to be larger for firms around the threshold, which are expected to experience the largest change in Quasi-indexer Ownership. 
Overall, our results are robust to controlling for sample selection and endogeneity concerns. Even though we cannot completely rule out these issues affecting our inferences, collectively our findings point to a causal effect of long-term institutional investors on labor investment efficiency. Still, since our tests do not directly capture monitoring by those investors (McCahery et al., 2016), our results should only be regarded as indirect inference about the role of long-term institutional investor monitoring in improving employment decisions.

\section{Additional analysis: the role of short-term investors}

We have focused on the role of long-term institutional investors since we consider them to be the shareholders primarily engaging in monitoring within a firm. Still, we acknowledge that there are alternative views in the extant literature regarding the monitoring incentives of short-term investors. Hence, we now perform additional analysis to test two different views about the impact of short-term ownership on labor investment efficiency. The first view predicts that short-term investors do not play an effective monitoring role and thus should not reduce abnormal net hiring. This is because short-term investors may have weak incentives to monitor managers, as they have little time to learn about the firm during the short period in which they hold its shares, and hence face significant monitoring costs (e.g., Gaspar et al., 2005). Due to the lack of effective monitoring, firms with short-term ownership tend to do worse in takeovers (Gaspar et al., 2005; Chen et al., 2007). Additionally, short-term investors may lead to managerial myopia (e.g., Stein, 1989; Froot et al., 1992; Von Thadden, 1995) and short-term incentives (Bolton et al., 2006). Managers concerned with short-term results may therefore engage in earnings management (e.g., Bushee, 1998) while under-investing to temporarily boost the short-term stock price (Bolton et al., 2006), especially if their actions are not likely to be detected and/or do not lead to wealth extraction from shareholders. Empirically, Cremers et al. (2019) provide causal evidence that the presence of short-horizon investors has a positive impact on short-term earnings but a negative one on long-term investment. 
However, the alternative view argues that short-term investors may improve firm governance and hence reduce labor investment inefficiency. This view is based on two arguments. First, activist hedge funds, typically classified as short-term, may propose strategic, operational, and financial improvements in firms, leading to increases in their long-term shareholder value (Brav et al., 2008; Brav et al., 2015; Boyson et al., 2017). Second, even when short-term investors are not activists, they may still play a monitoring role by incorporating relevant information about firms into their stock prices quickly through their trading (Edmans, 2009). However, for short-term investors to be effective monitors, they need to rely on the support of other types of investors, including investors with long horizons (Harford et al., 2018; Appel et al., 2019). Since short-term hedge funds tend to hold a small fraction of the firm's ownership, the success of their campaign may depend on the role of those investors with a vested interest in the firm, that is, investors with long horizons. Likewise, Harford et al. (2018) argue that even when short-term investors help provide value relevant information through stock price signals, it is the action by long-term investors that influences managers and ensures that these stock price signals are translated into appropriate corporate policies. Overall, these arguments suggest that, together with other investors, those investors with short investment horizons can help monitor firms and reduce labor investment inefficiency.

To test those conflicting views, we regress Abnormal_Net_Hiring on short-term ownership while controlling for the role of long-term investors. The results in Model 1 of Table 11 show that long-term investors have a significant and negative effect on labor investment inefficiency, consistent with our baseline finding. However, after controlling for long-horizon investors, the impact of short-term ownership is significant and positive, consistent with the first view that rather than playing a monitoring role, short-term investors might have incentives to exacerbate labor investment inefficiency. In the next two models of Table 11, we study the type of labor inefficiency short-term investors are associated with. In Model 2, there is no 
evidence that short-term ownership is associated with over-investment. Model 3, however, shows that short-term ownership is positively correlated with under-investment in labor, although the effect is only significant at the $10 \%$ level. In Models 4 and 5, we attempt to better understand when short-term investors are associated with under-investment. Specifically, we rerun our regression for subsamples of firms with different probabilities of earnings manipulation, measured using the M-score (Beneish, 1999). The results show that short-term investors are associated with firms that engage in under-investment and earnings management only when the likelihood of earnings manipulation being detected is low. Again, this finding is consistent with the first view about the role of short-term investors. In sum, our results provide evidence consistent with a "dark side" of short-term institutional ownership.

\section{Conclusion}

This paper examines the relationship between the investment horizon of institutional shareholders and the efficiency of their portfolio firms' labor investments. We argue that monitoring, or the threat of monitoring, by long-term investors deters managers from deviating from the optimal level of investment in employees. Consistent with this argument, we find that abnormal net hiring, measured as the absolute deviation from net hiring predicted by economic fundamentals, decreases in the presence of long-term investors. Our evidence suggests that the presence of long-term investors mitigates both over-investment and under-investment in labor.

We also show that the monitoring role of long-term investors is more pronounced for firms facing higher labor adjustment costs or higher costs of adjusting labor relative to capital, as well as those placing greater importance on their labor force. This finding supports the argument that long-term investors play a stronger monitoring role when deviation from the optimal labor demand policy would be more costly to the firm, or when human capital is more important to its business success. In further cross-sectional analysis, we find that the effect of long-term ownership on labor investment inefficiency is more pronounced for firms that are 
more complex, have weaker corporate governance, lower financial reporting quality, shortermaturity debt, male or older CEOs as well as different levels of managerial ownership, consistent with the idea that monitoring by long-term investors is more important for firms that have stronger incentives and/or greater opportunities to deviate from optimal net hiring.

To mitigate sample selection and endogeneity concerns, we perform several additional tests. Specifically, we estimate model specifications that control for alternative explanations. We also show that our main results hold for both potentially endogenous long-term nonindexers and plausibly exogenous long-term indexers, which helps mitigate sample selection concerns. In addition, we run analyses using PSM. Importantly, we conduct IV regressions aimed at examining the impact of exogenous changes to long-term ownership on changes in labor investment inefficiency as a result of the annual reconstitution of the Russell 1000 and 2000 indexes. The results from these analyses support our main findings and all point to a causal effect of long-term investment on labor investment efficiency.

However, caution should be taken in interpreting our results. Although our analyses consistently show that institutional investors play an important role in shaping firm-level employment decisions, they only provide indirect inference about the mechanism driving the result, namely, monitoring by long-term institutional investors. This is indeed a common drawback facing this line of research (Harford et al., 2018), since most of the monitoring by institutional owners involves private communication and "behind the scenes" intervention (McCahery et al., 2016), and hence is quite challenging to directly measure. Future research that can better capture the monitoring role of institutional investors is much warranted. 


\section{References}

Abernethy, M. A., Kuang, Y. F., Qin, B., 2019. The relation between strategy, CEO selection, and firm performance. Contemp. Account. Res. 36, 1575-1606.

Aghion, P., Van Reenen, J., Zingales, L., 2013. Innovation and institutional ownership. Am. Econ. Rev. 103, 277-304.

Alfaro, I., Bloom, N., Lin, X., 2019. The finance uncertainty multiplier. Working Paper, Fisher College of Business.

Andreou, P., Louca, C., Petrou, A., 2017. CEO age and stock price crash risk. Rev. Financ. 21, $1287-1325$.

Appel, I., Gormley, T., Keim, D., 2016. Passive investors, not passive owners. J. Financ. Econ. $121,111-141$.

Appel, I., Gormley, T., Keim, D., 2019. Standing on the shoulders of giants: The effect of passive investors on activism. Rev. Financ. Stud. 32, 2720-2774.

Ashbaugh-Skaife, H., Collins, D. W., Kinney, W. R., LaFond, R., 2008. The effect of SOX internal control deficiencies and their remediation on accrual quality. Account. Rev. 83, $217-250$.

Atanassov, J., Kim, E. H., 2009. Labor and corporate governance: international evidence from restructuring decisions. J. Financ. 64, 341-374.

Attig, N., Cleary, S., El Ghoul, S., Guedhami, O., 2012. Institutional investment horizon and investment-cash flow sensitivity. J. Bank. Financ. 36, 1164-1180.

Attig, N., Cleary, S., El Ghoul, S., Guedhami, O., 2013. Institutional investment horizons and the cost of equity capital. Financ. Manag. 42, 441-477.

Autor, D., Donohue III, J., Schwab, S., 2006. The costs of wrongful-discharge laws. Rev. Econ. Stat. 88, 211-231. 
Barclay, M., Smith, C. W., 1995. The maturity structure of corporate debt. J. Financ. 50, 609631.

Balakrishnan, K., Blouin, J., Guay, W., 2018. Tax aggressiveness and corporate transparency. Account. Rev. 94, 45-69.

Bebchuck, L., Cohen, A., Ferrell, A., 2009. What matters in corporate governance? Rev. Financ. Stud. 22, 783-827.

Becht, M., Franks, J., Mayer, C., Rossi, S., 2009. Returns to shareholder activism: evidence from a clinical study of the Hermes UK Focus Fund. Rev. Financ. Stud. 22, 3093-3129.

Belo, F., Lin, X., Li, J., Zhao, X., 2017. Labor-force heterogeneity and asset prices: the importance of skilled labor. Rev. Financ. Stud. 30, 3669-3709.

Beneish, M. D., 1999. The detection of earnings manipulation. Financ. Anal. J. 55, 24-36.

Benmelech, E., Bergman, N., Seru, A., 2015. Financing labor. Unpublished working paper. National Bureau of Economic Research, Cambridge.

Benmelech, E., Frydman, C., Papanikolaou, D., 2019. Financial frictions and employment during the Great Depression. J. Financ. Econ. 133, 541-563.

Ben-Nasr, H., Alshwer, A. A., 2016. Does stock price informativeness affect labor investment efficiency? J. Corp. Financ. 38, 249-271.

Bertrand, M., Mullainathan, S., 2003. Enjoying the quiet life? Corporate governance and managerial preferences. J. Polit. Econ. 111, 1043-1075.

Bhagat, S., Bolton, B., 2013. Director ownership, governance, and performance. J. Financ. Quant. Anal. 48, 105-135.

Biddle, G., Hilary, G., 2006. Accounting quality and firm-level capital investment. Account. Rev. 81, 963-982.

Biddle, G., Hilary, G., Verdi, R., 2009. How does financial reporting quality relate to investment efficiency? J. Account. Econ. 48, 112-131. 
Bloom, N. 2009. The impact of uncertainty shocks. Econometrica 77, 623-685.

Bolton, P., Scheinkman, J., Xiong, W., 2006. Executive compensation and short-term behavior in speculative markets. Rev. Econ. Stud. 73, 557-610.

Bond, S., Van Reenen, J., 2007. Microeconomic models of investment and employment. Handbook of Econometrics 6, 4417-4498.

Boyson, N. M., Gantchev, N., Shivdasani, A., 2017. Activism mergers. J. Financ. Econ. 126, $54-73$.

Brav, A., Jiang, W., Kim, H., 2015. The real effects of hedge fund activism, productivity, asset allocation, and labor outcomes. Rev. Financ. Stud. 28, 2723-2769.

Brav, A., Jiang, W., Partnoy, F., Thomas, R., 2008. Hedge fund activism, corporate governance, and firm performance. J. Financ. 63, 1729-1775.

Burns, N., Kedia, S., Lipson, M., 2010. Institutional ownership and monitoring: evidence from financial misreporting. J. Corp. Financ. 16, 443-455.

Bushee, B., 1998. The influence of institutional investors on myopic R\&D investment behavior. Account. Rev. 73, 305-333.

Bushee, B, 2001. Do institutional investors prefer near-term earnings over long-run value? Contemp. Account. Res. 18, 207-246.

Cain, M. D., McKeon, S. B., Solomon, S. D., 2017. Do takeover laws matter? Evidence from five decades of hostile takeovers. J. Financ. Econ. 124,464-485.

Campello, M., Cortes, G. S., D’Almeida, F., Kankanhalli, G., 2018. Exporting uncertainty: The impact of Brexit on corporate America. Working Paper, Cornell University.

Carleton, W. T., Nelson, J. M., Weisbach, M. S., 1998. The influence of institutions on corporate governance through private negotiations: evidence from TIAA-CREF. J. Financ. $53,1335-1362$. 
Cella, C., 2014. Institutional investors and corporate investment. Unpublished working paper. Stockholm School of Economics, Stockholm.

Cella, C., Ellul, A., Giannetti, M., 2013. Investors' horizons and the amplification of market shocks. Rev. Financ. Stud. 26, 1607-1648.

Chen, X., Harford, J., Li, K., 2007. Monitoring: which institutions matter? J. Financ. Econ. 86, 279-305.

Chen, W., Hribar, P., Melessa, S., 2018. Incorrect inferences when using residuals as dependent variables. J. Account. Res. 56, 751-796.

Cheng, M., Dhaliwal, D., Zhang, Y., 2013. Does investment efficiency improve after the disclosure of material weaknesses in internal control over financial reporting? J. Account. Econ. 56, 1-18.

Cheng, Q., Warfield, T. D., 2005. Equity incentives and earnings management. Account. Rev. $80,441-476$.

Chevalier, J., Ellison, G., 1999. Career concerns of mutual fund managers. Q. J. Econ. 114, $389-432$.

Chodorow-Reich, G., 2014. The employment effects of credit market disruptions: firm-level evidence from the 2008-9 financial crisis. Q. J. Econ. 129, 1-59.

Cook, D., Luo, S., 2018. Does managerial ownership affect investment efficiency? Causal evidence from the 2003 tax cut. Working paper. University of Alabama.

Crane, A. D., Michenaud, S., Weston, J. P., 2016. The effect of institutional ownership on payout policy: evidence from index thresholds. Rev. Financ. Stud. 29, 1377-1408.

Cremers, M., Pareek, A., Sautner, Z., 2019. Short-term investors, long-term investments, and firm value: Evidence from Russell 2000 index inclusions. Manag. Sci., forthcoming.

Cronqvist, H., Heyman, F., Nilsson, M., Svaleryd, H., Vlachos, J., 2009. Do entrenched managers pay their workers more? J. Financ. 64, 309-339. 
Daniel, N. D., Y. Li, and L. Naveen. 2019. Symmetry in pay for luck. Rev. Financ. Stud., forthcoming.

Dechow, P., Dichev, I., 2002. The quality of accruals and earnings: the role of accrual estimation errors. Account. Rev. 77, 35-59.

Dechow, P., Sloan, R., 1991. Executive incentives and the horizon problem: An empirical investigation. J. Account. Econ. 14, 51-89.

Del Guercio, D., Hawkins, J., 1999. The motivation and impact of pension fund activism. J. Financ. Econ. 52, 293-340.

Demerjian, P., Lev, B., McVay, S., 2012. Quantifying managerial ability: a new measure and validity tests. Manag. Sci. 58, 1229-1248.

Demers, E., Wang, C., 2010. The impact of CEO career concerns on accruals based and real earnings management. Working Paper, University of Lausanne.

Denis, D., Denis, D., Sarin, A., 1997. Agency problems, equity ownership, and corporate diversification. Journal of Finance 52, 135-160.

Derrien, F., Kecskés, A., Thesmar, D., 2013. Investor horizons and corporate policies. J. Financ. Quant. Anal. 48, 1755-1780.

Dixit, A., 1997. Investment and employment dynamics in the short run and the long run. Oxf. Econ. Pap. 49, 1-20.

Dixit, A.K., Pindyck, R.S., 1994. Investment under uncertainty. Princeton, NJ: Princeton Univeristy Press.

Dube, A., Freeman, E., Reich, M., 2010. Employee replacement costs. Working Paper, University of California, Berkeley.

Edmans, A., 2009. Blockholder trading, market efficiency, and managerial myopia. J. Financ. $64,2481-2513$. 
Eisdorfer, A., Giaccotto, C., White, R., 2013. Capital structure, executive compensation, and investment efficiency. J. Bank. Financ., 549-562.

Ellul, A., Pagano, M., Schivardi, F., 2018. Employment and wage insurance within firms: worldwide evidence. Rev. Financ. Stud. 31, 1298-1340.

Elyasiani, E., Jia, J., Mao, C. X., 2010. Institutional ownership stability and the cost of debt. J. Financ. Mark. 13, 475-500.

Falato, A., Liang, N., 2016. Do creditor rights increase employment risk? Evidence from loan covenants. J. Financ. 71, 2545-2590.

Falato, A., Kadyrzhanova, D., Sim, J., Steri, R. 2018. Rising intangible capital, shrinking debt capacity, and the U.S. corporate savings glut. Working paper, Federal Reserve Board.

Fama, E., French, K., 1997. Industry costs of equity. J. Financ. 43, 153-193.

Fazzari, S., Hubbard, R., Petersen, B., 1988. Financing constraints and corporate investment. Brookings Pap. Eco. Ac., 141-195.

Fenn, S., Robinson, B., 2009. Proxy Voting by Exchange-Traded Funds: an Analysis of ETF Voting Policies, Practices, and Patterns. IRRC Institute, New York.

Fich, E. M., Harford, J., Tran, A. L., 2015. Motivated monitors: the importance of institutional investors' portfolio weights. J. Financ. Econ. 118, 21-48.

Froot, K. A., Perold, A. F., Stein, J. C., 1992. Shareholder trading practices and corporate investment horizons. J. Appl. Corp. Financ. 5, 42-58.

Fung, S., Goodwin, J., 2013. Short-term debt maturity, monitoring and accruals-based earnings management. J. Contemp. Account. Econ. 9, 67-82.

Gao, H., Harford, J., Li, K., 2017. CEO turnover-performance sensitivity in private firms. J. Financ. Quant. Anal. 52, 583-611.

García Lara, J.M., García Osma, B., Penalva, F., 2016. Accounting conservatism and firm investment efficiency. J. Account. Econ. 61, 221-238. 
Gaspar, J., Massa, M., Matos, P., 2005. Shareholder investment horizons and the market for corporate control. J. Financ. Econ. 76, 135-165.

Gaspar, J., Massa, M., Matos, P., Patgiri, R., Rehman, Z., 2013. Payout policy choices and shareholder investment horizons. Rev. Financ. 17, 261-320.

Ghaly, M., Dang, V. A., Stathopoulos, K., 2017. Cash holdings and labor heterogeneity: the role of skilled labor. Rev. Financ. Stud. 30, 3636-3668.

Giroud, X., Mueller, H. M., 2017. Firm leverage, consumer demand, and employment losses during the great recession. Q. J. Econ. 132, 271-316.

Gompers, P., Ishii, J., Metrick, A., 2003. Corporate governance and equity prices. Q. J. Econ. $118,107-155$.

Gormley, T. A., Matsa, D. A., 2014. Common errors: how to (and not to) control for unobserved heterogeneity. Rev. Financ. Stud. 27, 617-661.

Gormley, T., Matsa, D., 2016. Playing it safe? Managerial preferences, risk, and agency conflicts. J. Financ. Econ. 122, 431-455.

Graham, J., Harvey, C., Rajgopal, S., 2005. The economic implications of corporate financial reporting. J. Account. Econ. 40, 3-73.

Gul, F., Goodwin, J., 2010. Short-term debt maturity structures, credit ratings, and the pricing of audit services. Account. Rev. 85, 877-909.

Gupta, M., Khurana, I. K., Pereira, R., 2008. Legal enforcement, short maturity debt, and the incentive to manage earnings. J. Law. Econ. 51, 619-639.

Hadlock, C., Pierce, J., 2010. New evidence on measuring financial constraints: Moving beyond the KZ index. Rev. Financ. Stud. 23,1909-1940.

Hall, R. 2004. Measuring factor adjustment costs. Q. J. Econ. 119, 899-927.

Hamermesh, D. S., 1989. Labor demand and the structure of adjustment costs. Am. Econ. Rev. 79, 674-689. 
Hamermesh, D., Pfann, G., 1996. Adjustment costs in factor demand. J. Econ. Lit. 34, 12641292.

Hao, Q., 2014. Institutional shareholder investment horizons and seasoned equity offerings. Financ. Manag. 43, 87-111.

Harford, J., Kecskés, A., Mansi, S., 2018. Do long-term investors improve corporate decision making? J. Corp. Financ. 50, 424-452.

Harvey, C. R., Lins, K. V., Roper, A. H., 2004. The effect of capital structure when expected agency costs are extreme. J. Financ. Econ. 74, 3-30.

Hassan, T., Hollander, S., van Lent, L., Tahoun, A., 2019. Firm-level political risk: Measurement and effects. Q. J. Econ., 134, 2135-2202.

Hoechle, D., Schmid, M., Walter, I., Yermack, D., 2012. How much of the diversification discount can be explained by poor corporate governance? J. Financ. Econ. 103, 41-60.

Hovakimian, A., Hu, H., 2016. Institutional shareholders and SEO market timing. J. Corp. Financ. 36, 1-14.

Huang, Q., Jiang, F., Wu, S.-Y. 2018. Does short-maturity debt discipline managers? Evidence from cash-rich firms’ acquisition decisions. J. Corp. Financ. 53, 133-154.

Huang, K., Petkevic, A., 2016. Corporate bond pricing and ownership heterogeneity. J. Corp. Financ. 36, 54-74.

Huang, H.-W., Rose-Green, E., Lee, C. 2012. CEO age and financial reporting quality. Account. Horiz. 26, 725-740.

Huang, J., Kisgen, J., 2013. Gender and corporate finance: Are male executives overconfident relative to female executives? J. Financ. Econ. 108, 822-839.

Jensen, M., 1986. Agency costs of free cash flow, corporate finance, and takeovers. Am. Econ. Rev. 76, 323-329.

Jenter, D., Lewellen, K., 2015. CEO preferences and acquisitions. J. Financ. 70, 2813-2852. 
Jung, B., Lee, W. J., Weber, D. P., 2014. Financial reporting quality and labor investment efficiency. Contemp. Account. Res. 31, 1047-1076.

Kaplan, S., Zingales. L., 1997. Do investment-cash flow sensitivities provide useful measures of financing constraints? Q. J. Econ. 112, 169-215.

Khedmati, M., Sualihu, M. A., Yawson, A., 2019. CEO-director ties and labor investment efficiency. J. Corp. Financ, forthcoming.

Kim, H., Kung, H., 2017. The asset redeployability channel: How uncertainty affects corporate investment. Rev. Financ. Stud. 30, 245-280.

Klasa, S., Ortiz-Molina, H., Serfling, M., Srinivasan, S. 2018. Protection of trade secrets and capital structure decisions. J. Fin. Econ. 128, 266-286.

LaFond, R., Roychowdhury, R., 2008. Managerial ownership and accounting conservatism. J. Account. Res. 46, 101-135.

Landier, A., Nair, V., Wulf, J., 2009. Tradeoffs in staying close: corporate decision-making and geographic dispersion. Rev. Financ. Stud. 22, 1119-1148.

Lau, S. T., Ng, L., Zhang, B., 2010. The world price of home bias. J. Financ. Econ. 97,191217.

Lim, C., Thong, T., Ding, D., 2008. Firm diversification and earnings management: evidence from seasoned equity offerings. Rev. Quant. Financ. Account. 30, 69-92.

Matsa, D., 2018. Capital structure and a firm's workforce. Annu. Rev. Financ. Econ. 10, $387-412$.

Merz, M., Yashiv, E., 2007. Labor and the market value of the firm. Am. Econ. Rev. 97, 14191431.

McCahery, J. A., Sautner, Z., Starks, L. T., 2016. Behind the scenes: the corporate governance preferences of institutional investors. J. Financ. 71, 2905-2932. 
McNichols, M., 2002. Discussion of the quality of accruals and earnings: the role of accrual estimation errors. Account. Rev. 77, 61-69.

Moretti, E., 2011. Local labor markets. Handb. Labor. Econ. 4B, 1237-1313.

Mortensen, D., Pissarides, C., 1994. Job creation and job destruction in the theory of unemployment. Rev. Econ. Stud. 61, 397-415.

Myers, S. C., 1977. Determinants of corporate borrowing. J. Financ. Econ. 5, 147-175.

Narayanan, M.P., 1985. Managerial incentives for short-term results. J. Financ. 40, 1469-1484.

Narayanan, M.P., 1996. Form of compensation and managerial decision horizon. J. Financ. Quant. Anal. 31, 467-491.

Neubaum, D. O., Zahra, S. A., 2006. Institutional ownership and corporate social performance: the moderating effects of investment horizon, activism, and coordination. J. Manage. 32, $108-131$.

Nguyen, P. A., Kecskés, A., Mansi, S., 2020. Does corporate social responsibility create shareholder value? The importance of long-term investors. J. Bank. Financ. 112, 105217.

Ochoa, M., 2013. Labor heterogeneity, volatility and expected equity returns. Unpublished working paper. Board of Governors of the Federal Reserve System, Washington.

Oi, W., 1962. Labor as a quasi-fixed factor. J. Polit. Econ. 70, 538-555.

Pagano, M., Volpin, P. F., 2005. Managers, workers, and corporate control. J. Financ. 60, 841868.

Perry, T., Shivdasani, A., 2005. Do boards affect performance? Evidence from corporate restructuring. J. Bus. 78, 1403-1431.

Pfann, G., Palm, F., 1993. Asymmetric adjustment costs in non-linear labour demand models for the Netherlands and U.K. manufacturing sectors. Rev. Econ. Stud. 60, 397-412.

Pfeffer, J., 1996. Competitive Advantage through People: unleashing the Power of the Work Force. Harvard Business Press, Cambridge. 
Pinnuck, M., Lillis, A., 2007. Profits versus losses: does reporting an accounting loss act as a heuristic trigger to exercise the abandonment option and divest employees? Account. Rev. $82,1031-1053$.

Porter, M., 1992. Capital choices: changing the way America invests in industry. J. Appl. Corp. Financ. 5, 4-16.

Richardson, S., 2006. Over-investment of free cash flow. Re. Account. Stud. 11, 159-189.

Shapiro, M. D. 1986. The dynamic demand for capital and labor. Q. J. Econ. 101, 513-542.

Schmidt, C., Fahlenbrach, R., 2017. Do exogenous changes in passive institutional ownership affect corporate governance and firm value? J. Financ. Econ. 124, 285-306.

Serfling, M., 2016. Firing costs and capital structure decisions. J. Financ. 71, 2239-2286.

Smith, C. W., 1986. Investment banking and the capital acquisition process. J. Financ. Econ. $15,3-29$.

Srinidhi, B., Gul, F., Tsui, J., 2011. Female directors and earnings quality. Contemp. Account. Res. 28, 1610-1644.

Stein, J. C., 1989. Efficient capital markets, inefficient firms: a model of myopic corporate behavior. Q. J. Econ. 104, 655-669.

Stoughton, N. M., Wong, K. P., Yi, L. 2016. Investment efficiency and product market competition. J. Financ. Quant. Anal. 52, 2611-2642.

Stulz, R. M., 1990. Managerial discretion and optimal financing policies. J. Financ. Econ. 26, $3-27$.

Sun, J., Liu, G., Lan, G., 2011. Does female directorship on independent audit committees constrain earnings management? J. Bus. Ethics 99, 369-382.

Titman, S., Wei, K. C. J., Xie, F., 2004. Capital investments and stock returns. J. Financ. Quant. Anal. 39, 677-700. 
Von Thadden, E. L., 1995. Long-term contracts, short-term investment and monitoring. Rev. Econ. Stud. 62, 557-575.

Ward, C., Yin, C., Zeng, Y., 2018. Institutional investor monitoring motivation and the marginal value of cash. J. Corp. Financ. 48, 49-75.

Warfield, T., Wild, J., Wild, K., 1995. Managerial ownership, accounting choices, and informativeness of earnings. J. Account. Econ. 20, 61-91.

Whited, T., Wu. G., 2006. Financial constraints risk. Rev. Financ. Stud. 19, 531-559.

Williamson, O., 1963. Managerial discretion and business behavior. Am. Econ. Rev. 53, 10321057.

Yan, X., Zhang, Z., 2009. Institutional investors and equity returns: are short-term institutions better informed? Rev. Financ. Stud. 22, 893-924.

Yim, S., 2013. The acquisitiveness of youth: CEO age and acquisition behavior. J. Financ. Econ. 108, 250-273.

Zingales, L., 2000. In search of new foundations. J. Financ. 55, 1623-1653. 


\section{Appendix A: Variable definitions}

\section{Ownership variables}

Investor_Turnover

Investor_Stability

Institutional Ownership

Dedicated_Ownership

Quasi-indexer_Ownership

Blockholdings
The weighted average of the turnover rates of all institutional investors in a firm's ownership structure based on Gaspar et al. (2005).

Investor_Turnover multiplied by -1 .

Percentage of shares owned by institutional investors.

Percentage of shares owned by dedicated institutional investors based on Bushee (1998).

Percentage of shares owned by quasi-indexed institutional investors based on Bushee (1998).

The number of institutions whose ownership is at least 5\% of the firm's outstanding shares.

\section{Labor investment variables}

Net_Hiring

Expected_Net_Hiring

Abnormal_Net_Hiring

Over-investment

Under-investment

Over-hiring

Under-firing

Under-hiring

Over-firing

\section{Firm characteristics}

Sales_Growth

Profit

$\Delta$ Profit

Return

Size

Quick_Ratio

Leverage

Loss_Bins

Market-to-book

\section{Dividend Dummy}

Cash Flow Volatility

Sales Volatility

Net Hiring Volatility

Tangibility

Loss Dummy

Labor Intensity

Abn_Non-labor_Invest
Percentage change in the number of employees (emp).

Expected percentage change in the number of employees ( and Lillis (2007) model.

|Actual_Net_Hiring - Expected_Net_Hiring

Positive abnormal net hiring.

Negative abnormal net hiring.

Over-investment when the expected level of net hiring is positive.

Over-investment when the expected level of net hiring is negative.

Under-investment when the expected level of net hiring is positive.

Under-investment when the expected level of net hiring is negative.

Percentage change in sales revenue (sale).

Net income (ni) scaled by beginning-of-year total assets (at).

The change in net income (ni) scaled by beginning-of-year total assets (at).

Total stock return in the last 12 months.

The logarithm of the firm's book value of assets (at).

The ratio of cash and short-term investments (che) plus receivables (rect) to current liabilities $(l c t)$.

Long-term debt $(d l t t)$ plus debt in current liabilities $(d l c)$, all scaled by the book value of assets $(a t)$.

Five dummy variables indicating each interval of profitability of length 0.005 from 0 to -0.025 . For example, Loss_Bin 1 takes the value of one if Profit is between -0.005 and 0 and zero otherwise, and so on for the other Loss_Bins.

Book value of assets $(a t)$ plus the market value of common equity $\left(\operatorname{prcc} \_f \times c s h o\right)$ minus the book value of common equity (ceq), all scaled by the book value of assets (at).

A dummy variable set equal to one in years in which a firm pays common dividends $(d v c)$, and zero otherwise.

The standard deviation of the ratio of firm-level cash flow (oibdp $-x i n t-t x t-d v c)$ to assets $(a t)$ for the previous five years.

The standard deviation of firm-level sales revenue (sale) for the previous five years.

The standard deviation of a firm's Net_Hiring for the previous five years.

The ratio of property, plant, and equipment (ppent) to total assets (at).

A dummy variable set equal to one in years in which a firm makes a loss $($ Profit $<0)$.

The ratio of the number of employees (emp) to total assets (at).

Abnormal non-labor investments, defined as the absolute value of the residual from the regression of Non-labor_Invest on Sales_Growth where Non-labor_Invest is measured 
Labor_Skill

$W D L$

Accounting Quality

Asset Redeployability

Firm Complexity

\section{Governance variables}

G-index

E-index

Direct_Own

Ind_Direct

Duality

Takeover Index as the sum of capital expenditure (capx), acquisition expenditure ( $a q c)$, and research and development expenditure $(x r d)$, less cash receipts from the sale of property, plant, and equipment (sppe), all scaled by lagged total assets.

A firm's reliance on skilled labor measured as Labor_Skill $l_{i}=\sum_{j=1}^{O}\left(\frac{E_{j i}}{E_{i}} * Z_{j}\right)$, where $E_{j i}$ is the number of employees in industry $i$ working in occupation $j, E_{i}$ is the total number of employees in industry $\mathrm{i}, \mathrm{O}$ is the total number of occupations in industry $\mathrm{i}$, and $\mathrm{Z}_{\mathrm{j}}$ is the U.S. Department of Labor's O*NET program classification of occupations based on skill level.

WDL measures the strength of Wrongful Discharge Laws (WDLs) in the state where the firm is headquartered and is constructed by summing three distinct dummy variables for each of the three WDLs exceptions, where each dummy is set equal to one if the firm is in a state that has adopted the exception in question, and zero otherwise.

Accounting Quality is defined based on Dechow and Dichev's (2002) model and its modification by McNichols (2002). The model is a regression of working capital accruals on one-year-lagged, current, and one-year-ahead cash flows from operations, the change in revenue, and property, plant, and equipment. The model is estimated by industry-year and the residuals are collected. We then compute the standard deviation of the residuals over the years $\mathrm{t}-5$ to $\mathrm{t}-1$. The standard deviation is then multiplied by -1 . measures the extent to which a firm's assets have alternative uses within and across industries; based on Kim and Kung (2017).

A firm is defined as complex if it has more than two business segments.

The Gompers et al. (2003) corporate governance index of 24 antitakeover provisions

The Bebchuck et al. (2009) managerial entrenchment index.

The natural log of the dollar value of common stock owned by the median director based on Bhagat and Bolton (2013).

The percentage of board members classified as independent.

An indicator variable that takes the value of one if the CEO of the sample firm is also the board chair, and zero otherwise.

Cain et al.'s (2017) index of takeover susceptibility constructed using determinants from the legal environment and other plausibly exogenous variables such as aggregate capital liquidity and firm age.

\section{Managerial characteristics}

resources to revenues based on Demerjian et al. (2012). 


\section{Appendix B: Table B. Estimation of the expected level of net hiring}

This table reports the regression results for the estimation of the expected level of net hiring using Pinnuck and Lillis' (2007) labor demand model. All variables are defined in Appendix A. The $t$-statistics in parentheses are based on robust standard errors clustered at the firm level. $* * * * *$, and $*$ denote statistical significance at the $1 \%$, $5 \%$, and $10 \%$ levels, respectively.

Dependent variable: Net hiring

\begin{tabular}{|c|c|c|}
\hline Variables & $\begin{array}{l}\text { Predicted } \\
\text { Sign }\end{array}$ & \\
\hline Sales_Growth $\mathrm{t}$ & + & $\begin{array}{l}0.313 * * * \\
(28.96)\end{array}$ \\
\hline Sales_Growth t-1 & + & $\begin{array}{l}0.050 * * * \\
(9.37)\end{array}$ \\
\hline Profit $_{t}$ & + & $\begin{array}{l}0.090 * * * \\
(5.45)\end{array}$ \\
\hline$\Delta$ Profit $_{\mathrm{t}}$ & - & $\begin{array}{l}-0.030 \\
(-1.48)\end{array}$ \\
\hline$\Delta$ Profit $_{\mathrm{t}-1}$ & + & $\begin{array}{l}-0.001 \\
(-1.09)\end{array}$ \\
\hline Return $_{\mathrm{t}}$ & + & $\begin{array}{c}0.027 * * * \\
(10.83)\end{array}$ \\
\hline Size $_{t-1}$ & + & $\begin{array}{l}0.003 * * * \\
(6.68)\end{array}$ \\
\hline Quick_Ratio t-1 & + & $\begin{array}{c}0.008 * * * \\
(8.42)\end{array}$ \\
\hline$\Delta$ Quick_Ratio t-1 & + & $\begin{array}{l}0.000 * * * \\
(2.60)\end{array}$ \\
\hline$\Delta$ Quick_Ratio t & $+/-$ & $\begin{array}{l}-0.001 \\
(-0.64)\end{array}$ \\
\hline Leverage $_{t-1}$ & - & $\begin{array}{l}-0.062 * * * \\
(-9.33)\end{array}$ \\
\hline Loss_Bin $1 \mathrm{t}-1$ & - & $\begin{array}{l}-0.018 * * \\
(-2.35)\end{array}$ \\
\hline Loss_Bin $2 \mathrm{t}-1$ & - & $\begin{array}{l}-0.027 * * * \\
(-3.92)\end{array}$ \\
\hline Loss_Bin $3 \mathrm{t}-1$ & - & $\begin{array}{l}-0.019 * * \\
(-2.23)\end{array}$ \\
\hline Loss_Bin4 t-1 & - & $\begin{array}{l}-0.011 \\
(-1.18)\end{array}$ \\
\hline Loss_Bin5 t-1 & - & $\begin{array}{l}-0.019 * * \\
(-2.15)\end{array}$ \\
\hline Intercept & $+/-$ & $\begin{array}{l}-0.017 * * * \\
(-4.28)\end{array}$ \\
\hline Industry fixed effects & & Yes \\
\hline Observations & & 51,414 \\
\hline Adjusted $\mathrm{R}^{2}$ & & 0.23 \\
\hline
\end{tabular}




\section{Table 1. Summary statistics}

This table presents summary statistics for the labor investment, ownership, and control variables used in our main analysis. We also report descriptive statistics for the control variables used in the estimation of the expected level of net hiring. Our sample consists of 51,414 firm-year observations representing 6,313 unique firms over the period 1982 to 2015. All variables are defined in Appendix A.

\begin{tabular}{|c|c|c|c|c|c|}
\hline Variable & Mean & Std. Dev. & Median & Q1 & $\mathrm{Q} 4$ \\
\hline \multicolumn{6}{|c|}{ Labor investment variables: } \\
\hline Actual_Net_Hiring & 0.050 & 0.245 & 0.020 & -0.050 & 0.110 \\
\hline Expected_Net_Hiring & 0.050 & 0.116 & 0.040 & -0.004 & 0.085 \\
\hline Abnormal_Net_Hiring & 0.123 & 0.177 & 0.070 & 0.032 & 0.142 \\
\hline \multicolumn{6}{|l|}{ Ownership variables: } \\
\hline Investor_Turnover & 0.191 & 0.059 & 0.187 & 0.155 & 0.220 \\
\hline Dedicated Ownership & 0.055 & 0.069 & 0.032 & 0.007 & 0.078 \\
\hline Quasi-indexer Ownership & 0.303 & 0.203 & 0.287 & 0.123 & 0.465 \\
\hline Institutional Ownership & 0.434 & 0.277 & 0.425 & 0.184 & 0.669 \\
\hline \multicolumn{6}{|l|}{ Other variables: } \\
\hline Sales_Growth & 0.105 & 0.326 & 0.069 & -0.021 & 0.175 \\
\hline Profit & 0.020 & 0.165 & 0.047 & -0.003 & 0.092 \\
\hline Return & 0.173 & 0.596 & 0.085 & -0.178 & 0.381 \\
\hline Size & 5.606 & 2.011 & 5.470 & 4.127 & 6.955 \\
\hline Quick_Ratio & 1.822 & 2.075 & 1.226 & 0.800 & 2.006 \\
\hline Leverage & 0.220 & 0.201 & 0.191 & 0.049 & 0.330 \\
\hline Market-to-book & 2.527 & 3.446 & 1.782 & 1.088 & 2.995 \\
\hline Dividend Dummy & 0.440 & 0.496 & 0.000 & 0.000 & 1.000 \\
\hline Cash Flow Volatility & 0.058 & 0.334 & 0.029 & 0.016 & 0.057 \\
\hline Sales Volatility & 0.187 & 0.648 & 0.132 & 0.077 & 0.225 \\
\hline Tangibility & 0.291 & 0.216 & 0.240 & 0.122 & 0.404 \\
\hline Loss Dummy & 0.257 & 0.437 & 0.000 & 0.000 & 1.000 \\
\hline Net Hiring Volatility & 0.285 & 2.388 & 0.131 & 0.073 & 0.230 \\
\hline Labor Intensity & 0.010 & 0.011 & 0.007 & 0.003 & 0.013 \\
\hline Abn_Non-labor_Invest & 0.096 & 0.112 & 0.075 & 0.040 & 0.110 \\
\hline
\end{tabular}




\section{Table 2. The relation between investor horizons and abnormal net hiring}

This table reports the regression results on the impact of institutional investment horizons on abnormal net hiring. In Model 1, we regress Abnormal_Net_Hiring on the set of control variables, and industry and year fixed effects. In Model 2, we include Investor_Stability as an additional explanatory variable. In Model 3, we repeat the specification of Model 2 but also control for state fixed effects. In Model 4, we include industry-year and stateyear fixed effects instead of controlling for industry, year, and state fixed effects separately. All variables are defined in Appendix A. The $t$-statistics in parentheses are based on robust standard errors clustered at the firm level. $* * *, * *$, and $*$ denote statistical significance at the $1 \%, 5 \%$, and $10 \%$ levels, respectively.

\begin{tabular}{|c|c|c|c|c|}
\hline Variables & (1) & (2) & (3) & (4) \\
\hline Investor_Stability t -1 & & $\begin{array}{c}-0.106 * * * \\
(-5.91)\end{array}$ & $\begin{array}{c}-0.104 * * * \\
(-5.74)\end{array}$ & $\begin{array}{c}-0.113 * * * \\
(-6.11)\end{array}$ \\
\hline Institutional Ownership $t-1$ & $\begin{array}{c}-0.024 * * * \\
(-5.20)\end{array}$ & $\begin{array}{c}-0.028 * * * \\
(-5.85)\end{array}$ & $\begin{array}{c}-0.027 * * * \\
(-5.78)\end{array}$ & $\begin{array}{c}-0.028 * * * \\
(-5.61)\end{array}$ \\
\hline Market-to-book t-1 & $\begin{array}{c}0.001 * * * \\
(3.52)\end{array}$ & $\begin{array}{c}0.001 * * * \\
(3.31)\end{array}$ & $\begin{array}{c}0.001 * * * \\
(3.31)\end{array}$ & $\begin{array}{c}0.001 * * * \\
(3.30)\end{array}$ \\
\hline Size $_{t-1}$ & $\begin{array}{c}-0.005 * * * \\
(-7.28)\end{array}$ & $\begin{array}{c}-0.005 * * * \\
(-7.52)\end{array}$ & $\begin{array}{c}-0.006 * * * \\
(-7.60)\end{array}$ & $\begin{array}{c}-0.006 * * * \\
(-7.30)\end{array}$ \\
\hline Quick_Ratio t-1 & $\begin{array}{c}0.007 * * * \\
(9.84)\end{array}$ & $\begin{array}{c}0.007 * * * \\
(9.78)\end{array}$ & $\begin{array}{c}0.007 * * * \\
(9.84)\end{array}$ & $\begin{array}{c}0.007 * * * \\
(9.81)\end{array}$ \\
\hline Leverage $_{\mathrm{t}-1}$ & $\begin{array}{c}0.026 * * * \\
(4.06)\end{array}$ & $\begin{array}{c}0.025 * * * \\
(3.99)\end{array}$ & $\begin{array}{c}0.025 * * * \\
(3.94)\end{array}$ & $\begin{array}{c}0.027 * * * \\
(4.00)\end{array}$ \\
\hline Dividend Dummy t-1 & $\begin{array}{c}-0.015 * * * \\
(-7.30)\end{array}$ & $\begin{array}{c}-0.014 * * * \\
(-6.62)\end{array}$ & $\begin{array}{c}-0.013 * * * \\
(-6.17)\end{array}$ & $\begin{array}{c}-0.012 * * * \\
(-5.59)\end{array}$ \\
\hline Cash Flow Volatility t-1 & $\begin{array}{l}-0.000 \\
(-0.11)\end{array}$ & $\begin{array}{l}-0.001 \\
(-0.17)\end{array}$ & $\begin{array}{l}-0.001 \\
(-0.19)\end{array}$ & $\begin{array}{l}-0.001 \\
(-0.43)\end{array}$ \\
\hline Sales Volatility t-1 & $\begin{array}{l}0.005 \\
(1.28)\end{array}$ & $\begin{array}{l}0.005 \\
(1.28)\end{array}$ & $\begin{array}{l}0.005 \\
(1.36)\end{array}$ & $\begin{array}{l}0.006 \\
(1.38)\end{array}$ \\
\hline Tangibility $\mathrm{t}-1$ & $\begin{array}{c}-0.039 * * * \\
(-5.42)\end{array}$ & $\begin{array}{c}-0.039 * * * \\
(-5.35)\end{array}$ & $\begin{array}{c}-0.038 * * * \\
(-5.30)\end{array}$ & $\begin{array}{c}-0.038 * * * \\
(-5.23)\end{array}$ \\
\hline Loss Dummy t-1 & $\begin{array}{c}0.022 * * * \\
(9.70)\end{array}$ & $\begin{array}{c}0.022 * * * \\
(9.83)\end{array}$ & $\begin{array}{c}0.022 * * * \\
(9.89)\end{array}$ & $\begin{array}{c}0.021 * * * \\
(9.21)\end{array}$ \\
\hline Net Hiring Volatility t-1 & $\begin{array}{c}0.002 * * * \\
(2.88)\end{array}$ & $\begin{array}{c}0.002 * * \\
(2.83)\end{array}$ & $\begin{array}{c}0.002 * * * \\
(2.84)\end{array}$ & $\begin{array}{c}0.002 * * \\
(2.55)\end{array}$ \\
\hline Labor Intensity t-1 & $\begin{array}{c}-0.655^{* * *} * \\
(-5.24)\end{array}$ & $\begin{array}{c}-0.648 * * * \\
(-5.19)\end{array}$ & $\begin{array}{c}-0.647 * * * \\
(-5.16)\end{array}$ & $\begin{array}{c}-0.643 * * * \\
(-4.80)\end{array}$ \\
\hline Abn_Non-labor_Invest $\mathrm{t}$ & $\begin{array}{c}0.455^{* * *} * \\
(27.40)\end{array}$ & $\begin{array}{c}0.453 * * * \\
(27.37)\end{array}$ & $\begin{array}{c}0.451 * * * \\
(27.23)\end{array}$ & $\begin{array}{c}0.452 * * * \\
(27.01)\end{array}$ \\
\hline Intercept & $\begin{array}{c}0.120 * * * \\
(6.62)\end{array}$ & $\begin{array}{c}0.105^{* * *} * \\
(5.73) \\
\end{array}$ & $\begin{array}{c}0.127 * * * \\
(5.26)\end{array}$ & $\begin{array}{c}0.120 * * * \\
(5.01)\end{array}$ \\
\hline Year fixed effects & Yes & Yes & Yes & $\mathrm{No}$ \\
\hline Industry fixed effects & Yes & Yes & Yes & No \\
\hline State fixed effects & No & No & Yes & No \\
\hline Industry-year fixed effects & No & No & No & Yes \\
\hline State-year fixed effects & No & No & No & Yes \\
\hline Observations & 51,414 & 51,414 & 51,414 & 51,241 \\
\hline Adjusted R ${ }^{2}$ & 0.15 & 0.15 & 0.15 & 0.15 \\
\hline
\end{tabular}




\section{Table 3. Investor horizon and specific types of labor investment inefficiency}

This table reports the regression results on the impact of institutional investment horizon on specific types of labor investment inefficiency. In Panel A, we examine the relation between investor horizon and over-investment in labor. Panel B reports the results on the relation between investor horizon and under-investment in labor. In Models 1 and 2 of Panel A, we estimate Eq. (6) for a subsample of over-investing firms where over-investment is defined as positive abnormal net hiring. In Models 3-6 of Panel A, we further decompose over-investment into over-hiring and under-firing. A firm over-hires (under-fires) if it over-invests when its expected level of net hiring is positive (negative). In Models 1 and 2 of Panel B, we estimate Eq. (6) for a subsample of under-investing firms, where under-investment is defined as negative abnormal net hiring. In Models 3-6 of Panel B, we further decompose under-investment into under-hiring and over-firing. A firm under-hires (over-fires) if it under-invests when its expected level of net hiring is positive (negative). All regressions include year and industry fixed effects, and all the covariates from our baseline specification. In Models 2, 4, and 6, we also control for state fixed effects. All variables are defined in Appendix A. The $t$-statistics in parentheses are based on robust standard errors clustered at the firm level. ***,**, and * denote statistical significance at the $1 \%, 5 \%$, and $10 \%$ levels, respectively.

Panel A. The relation between investor horizon and over-investment in labor

\begin{tabular}{|c|c|c|c|c|c|c|}
\hline \multirow[b]{2}{*}{ Variables } & \multicolumn{2}{|c|}{ Over-investment } & \multicolumn{2}{|c|}{ Over-hiring } & \multicolumn{2}{|c|}{ Under-firing } \\
\hline & $(1)$ & $(2)$ & (3) & (4) & $(5)$ & $(6)$ \\
\hline Investor_Stability t -1 & $\begin{array}{c}-0.137 * * * \\
(-4.51)\end{array}$ & $\begin{array}{c}-0.135 * * * \\
(-4.45)\end{array}$ & $\begin{array}{c}-0.141 * * * \\
(-3.67)\end{array}$ & $\begin{array}{c}-0.139 * * * \\
(-3.62)\end{array}$ & $\begin{array}{c}-0.106 * * \\
(-2.15)\end{array}$ & $\begin{array}{c}-0.105 * * \\
(-2.10)\end{array}$ \\
\hline Controls & Yes & Yes & Yes & Yes & Yes & Yes \\
\hline Year fixed effects & Yes & Yes & Yes & Yes & Yes & Yes \\
\hline Industry fixed effects & Yes & Yes & Yes & Yes & Yes & Yes \\
\hline State fixed effects & No & Yes & No & Yes & No & Yes \\
\hline Observations & 21,422 & 21,422 & 15,816 & 15,816 & 5,606 & 5,606 \\
\hline Adjusted $\mathrm{R}^{2}$ & 0.17 & 0.17 & 0.18 & 0.18 & 0.14 & 0.14 \\
\hline
\end{tabular}

Panel B. The relation between investor horizon and under-investment in labor

\begin{tabular}{|c|c|c|c|c|c|c|}
\hline \multirow[b]{2}{*}{ Variables } & \multicolumn{2}{|c|}{ Under-investment } & \multicolumn{2}{|c|}{ Under-hiring } & \multicolumn{2}{|c|}{ Over-firing } \\
\hline & $(1)$ & $(2)$ & (3) & $(4)$ & $(5)$ & $(6)$ \\
\hline Investor_Stability $\mathrm{t}-1$ & $\begin{array}{c}-0.066 * * * \\
(-3.97)\end{array}$ & $\begin{array}{c}-0.063 * * * \\
(-3.76)\end{array}$ & $\begin{array}{c}-0.097 * * * \\
(-4.58)\end{array}$ & $\begin{array}{c}-0.094 * * * \\
(-4.44)\end{array}$ & $\begin{array}{l}-0.003 \\
(-0.12)\end{array}$ & $\begin{array}{l}0.001 \\
(0.02)\end{array}$ \\
\hline Controls & Yes & Yes & Yes & Yes & Yes & Yes \\
\hline Year fixed effects & Yes & Yes & Yes & Yes & Yes & Yes \\
\hline Industry fixed effects & Yes & Yes & Yes & Yes & Yes & Yes \\
\hline State fixed effects & No & Yes & No & Yes & No & Yes \\
\hline Observations & 29,992 & 29,992 & 21,727 & 21,727 & 8,265 & 8,265 \\
\hline Adjusted $\mathrm{R}^{2}$ & 0.16 & 0.16 & 0.19 & 0.19 & 0.09 & 0.09 \\
\hline
\end{tabular}




\section{Table 4. The role of labor adjustment costs}

This table presents the impact of institutional investment horizon on abnormal net hiring for firms facing high labor adjustment costs (LACs) versus firms facing low LACs. In Panel A, we proxy for LACs using the strength of wrongful discharge laws $(W D L)$ in the state where a firm is headquartered. For each year, we define firms with a $W D L$ score of 3 (i.e., firms in states that recognize all three exceptions) as high LACs firms and those with a WDL score of 0 (i.e., firms in states that recognize none of the exceptions) as low LACs firms. In Panel B, we proxy for LACs using firms' reliance on skilled labor (Labor_Skill). For each year, we define firms in the top (bottom) $30^{\text {th }}$ percentile of Labor_Skill as high (low) LACs firms. The last row reports the p-values of the $F$-tests for differences in the coefficients on Investor_Stability for the two subsamples of high and low LACs firms. All regressions include year and industry fixed effects. All variables are defined in Appendix A. The $t$-statistics in parentheses are based on robust standard errors clustered at the firm level. ***, **, and * denote statistical significance at the $1 \%, 5 \%$, and $10 \%$ levels, respectively.

Panel A. Proxy for LACs: Wrongful discharge laws

\begin{tabular}{|c|c|c|c|c|c|c|}
\hline & \multicolumn{2}{|c|}{ Whole Sample } & \multicolumn{2}{|c|}{ Over-investment } & \multicolumn{2}{|c|}{ Under-investment } \\
\hline Variables & $\begin{array}{l}\text { High } \\
\text { LACs } \\
(1)\end{array}$ & $\begin{array}{l}\text { Low } \\
\text { LACs } \\
(2)\end{array}$ & $\begin{array}{l}\text { High } \\
\text { LACs } \\
(3)\end{array}$ & $\begin{array}{l}\text { Low } \\
\text { LACs } \\
(4)\end{array}$ & $\begin{array}{l}\text { High } \\
\text { LACs } \\
(5)\end{array}$ & $\begin{array}{l}\text { Low } \\
\text { LACs } \\
(6)\end{array}$ \\
\hline Investor_Stability t-1 & $\begin{array}{c}-0.248 * * * \\
(-4.14)\end{array}$ & $\begin{array}{l}-0.060 \\
(-1.33)\end{array}$ & $\begin{array}{c}-0.373 * * * \\
(-3.61)\end{array}$ & $\begin{array}{l}-0.050 \\
(-0.67)\end{array}$ & $\begin{array}{c}-0.111 * * \\
(-2.16)\end{array}$ & $\begin{array}{l}-0.014 \\
(-0.42)\end{array}$ \\
\hline Controls & Yes & Yes & Yes & Yes & Yes & Yes \\
\hline Year fixed effects & Yes & Yes & Yes & Yes & Yes & Yes \\
\hline Industry fixed effects & Yes & Yes & Yes & Yes & Yes & Yes \\
\hline Observations & 6,502 & 7,515 & 2,827 & 3,072 & 3,675 & 4,443 \\
\hline Adjusted $\mathrm{R}^{2}$ & 0.19 & 0.17 & 0.19 & 0.20 & 0.24 & 0.13 \\
\hline $\begin{array}{l}\text { p-value ( } F \text {-test of equal } \\
\text { coefficient estimates on } \\
\text { Investor_Stability) }\end{array}$ & $(0.01)$ & & $(0.01)$ & & $(0.12)$ & \\
\hline
\end{tabular}

Panel B. Proxy for LACs: Reliance on skilled labor

\begin{tabular}{|c|c|c|c|c|c|c|}
\hline & \multicolumn{2}{|c|}{ Whole Sample } & \multicolumn{2}{|c|}{ Over-investment } & \multicolumn{2}{|c|}{ Under-investment } \\
\hline Variables & $\begin{array}{l}\text { High } \\
\text { LACs } \\
\text { (1) }\end{array}$ & $\begin{array}{l}\text { Low } \\
\text { LACs } \\
(2)\end{array}$ & $\begin{array}{l}\text { High } \\
\text { LACs } \\
(3)\end{array}$ & $\begin{array}{l}\text { Low } \\
\text { LACs } \\
(4)\end{array}$ & $\begin{array}{l}\text { High } \\
\text { LACs } \\
(5)\end{array}$ & $\begin{array}{l}\text { Low } \\
\text { LACs } \\
(6)\end{array}$ \\
\hline Investor_Stability t -1 & $\begin{array}{c}-0.124 * * * \\
(-3.18)\end{array}$ & $\begin{array}{l}-0.025 \\
(-0.71)\end{array}$ & $\begin{array}{c}-0.192 * * * \\
(-3.07)\end{array}$ & $\begin{array}{l}0.012 \\
(0.19)\end{array}$ & $\begin{array}{l}-0.052 \\
(-1.44)\end{array}$ & $\begin{array}{l}-0.045 \\
(-1.29)\end{array}$ \\
\hline Controls & Yes & Yes & Yes & Yes & Yes & Yes \\
\hline Year fixed effects & Yes & Yes & Yes & Yes & Yes & Yes \\
\hline Industry fixed effects & Yes & Yes & Yes & Yes & Yes & Yes \\
\hline Observations & 11,313 & 5,186 & 4,745 & 2,159 & 6,568 & 3,027 \\
\hline $\begin{array}{l}\text { Adjusted } \mathrm{R}^{2} \\
\text { p-value ( } F \text {-test of equal } \\
\text { coefficient estimates on } \\
\text { Investor_Stability) }\end{array}$ & $\begin{array}{c}0.16 \\
(0.06)\end{array}$ & 0.14 & $\begin{array}{c}0.18 \\
(0.02)\end{array}$ & 0.17 & $\begin{array}{c}0.21 \\
(0.89)\end{array}$ & 0.12 \\
\hline
\end{tabular}




\section{Table 5. The role of differences between labor and capital adjustment costs.}

This table presents the impact of institutional investment horizon on abnormal net hiring for firms facing varying degrees of labor and capital adjustment costs. In Panels A and B, we report the results for firms with a high (abovemedian) ratio of labor adjustment costs (LACs) to capital adjustment costs (CACs) versus firms with a low (belowmedian) ratio of LACs to CACs. In Panel A, we proxy for LACs using firms' reliance on skilled labor, and we proxy for CACs using firms' asset redeployability (Kim and Kung, 2017). In Panel B, we measure LACs and CACs using the industry estimates from Hall (2004). The last row reports the p-values of the $F$-tests for differences in the coefficients on Investor_Stability for the compared subsamples. All regressions include year and industry fixed effects. All the other variables are defined in Appendix A. The $t$-statistics in parentheses are based on robust standard errors clustered at the firm level. ***,**, and * denote statistical significance at the $1 \%, 5 \%$, and $10 \%$ levels, respectively.

Panel A. Ratio of labor to capital adjustment costs: Labor skill and asset redeployability

\begin{tabular}{|c|c|c|c|c|c|c|}
\hline & \multicolumn{2}{|c|}{ Whole Sample } & \multicolumn{2}{|c|}{ Over-investment } & \multicolumn{2}{|c|}{ Under-investment } \\
\hline Variables & $\begin{array}{l}\text { High } \\
\text { LACs/ } \\
\text { CACs } \\
(1) \\
\end{array}$ & $\begin{array}{l}\text { Low } \\
\text { LACs/ } \\
\text { CACs } \\
(2) \\
\end{array}$ & $\begin{array}{l}\text { High } \\
\text { LACs/ } \\
\text { CACs } \\
(3) \\
\end{array}$ & $\begin{array}{l}\text { Low } \\
\text { LACs/ } \\
\text { CACs } \\
(4) \\
\end{array}$ & $\begin{array}{l}\text { High } \\
\text { LACs/ } \\
\text { CACs } \\
(5) \\
\end{array}$ & $\begin{array}{l}\text { Low } \\
\text { LACs/ } \\
\text { CACs } \\
(6) \\
\end{array}$ \\
\hline Investor_Stability t-1 & $\begin{array}{c}-0.280 * * * \\
(-7.03)\end{array}$ & $\begin{array}{c}-0.138 * * * \\
(-3.63)\end{array}$ & $\begin{array}{c}-0.374 * * * \\
(-5.57)\end{array}$ & $\begin{array}{c}-0.154 * * \\
(-2.46)\end{array}$ & $\begin{array}{c}-0.167 * * * \\
(-4.33)\end{array}$ & $\begin{array}{c}-0.110 * * * \\
(-3.27)\end{array}$ \\
\hline Controls & Yes & Yes & Yes & Yes & Yes & Yes \\
\hline Year fixed effects & Yes & Yes & Yes & Yes & Yes & Yes \\
\hline Industry fixed effects & Yes & Yes & Yes & Yes & Yes & Yes \\
\hline Observations & 12,881 & 12,530 & 5,262 & 5,321 & 7,268 & 7,560 \\
\hline $\begin{array}{l}\text { Adjusted } \mathrm{R}^{2} \\
\mathrm{p} \text {-value ( } F \text {-test of equal } \\
\text { coefficient estimates on } \\
\text { Investor Stability) }\end{array}$ & $\begin{array}{c}0.15 \\
(0.01)\end{array}$ & 0.18 & $\begin{array}{c}0.19 \\
(0.02)\end{array}$ & 0.17 & $\begin{array}{c}0.22 \\
(0.26)\end{array}$ & 0.15 \\
\hline
\end{tabular}

Panel B. Ratio of labor to capital adjustment costs: Industry estimates

\begin{tabular}{|c|c|c|c|c|c|c|}
\hline & \multicolumn{2}{|c|}{ Whole Sample } & \multicolumn{2}{|c|}{ Over-investment } & \multicolumn{2}{|c|}{ Under-investment } \\
\hline Variables & $\begin{array}{l}\text { High } \\
\text { LACs/ } \\
\text { CACs } \\
(1)\end{array}$ & $\begin{array}{c}\text { Low } \\
\text { LACs/ } \\
\text { CACs } \\
(2) \\
\end{array}$ & $\begin{array}{l}\text { High } \\
\text { LACs/ } \\
\text { CACs } \\
(3)\end{array}$ & $\begin{array}{l}\text { Low } \\
\text { LACs/ } \\
\text { CACs } \\
(4)\end{array}$ & $\begin{array}{l}\text { High } \\
\text { LACs/ } \\
\text { CACs } \\
(5)\end{array}$ & $\begin{array}{c}\text { Low } \\
\text { LACs/ } \\
\text { CACs } \\
(6)\end{array}$ \\
\hline Investor_Stability t -1 & $\begin{array}{c}-0.143 * * * \\
(-4.43)\end{array}$ & $\begin{array}{l}-0.047 \\
(-1.45)\end{array}$ & $\begin{array}{c}-0.134 * * * \\
(-2.62)\end{array}$ & $\begin{array}{l}-0.091 \\
(-1.47)\end{array}$ & $\begin{array}{c}-0.118 * * * \\
(-3.38)\end{array}$ & $\begin{array}{l}-0.008 \\
(-0.28)\end{array}$ \\
\hline Controls & Yes & Yes & Yes & Yes & Yes & Yes \\
\hline Year fixed effects & Yes & Yes & Yes & Yes & Yes & Yes \\
\hline Industry fixed effects & Yes & Yes & Yes & Yes & Yes & Yes \\
\hline Observations & 14,690 & 13,922 & 5,599 & 5,400 & 9,091 & 8,522 \\
\hline $\begin{array}{l}\text { Adjusted } \mathrm{R}^{2} \\
\text { p-value ( } F \text {-test of equal } \\
\text { coefficient estimates on } \\
\text { Investor_Stability) }\end{array}$ & $\begin{array}{c}0.19 \\
(0.03)\end{array}$ & 0.14 & $\begin{array}{c}0.19 \\
(0.59)\end{array}$ & 0.19 & $\begin{array}{c}0.24 \\
(0.01)\end{array}$ & 0.11 \\
\hline
\end{tabular}




\section{Table 6. The importance of human capital}

This table shows how the impact of institutional investment horizon on abnormal net hiring is affected by the importance that the firm attaches to its employees. In Panel A, we proxy for the importance of human capital to a firm using R\&D intensity measured as the ratio of $R \& D$ expenditure to total assets. Each year, we define firms with above (below)-median R\&D expenditure to total assets as high (low)-R\&D-intensive. In Panel B, we proxy for the importance of human capital using intangible capital intensity. We follow Peters and Taylor (2017) and define Intangible capital as the sum of internally created and externally purchased intangible capital. We measure the stock of internally created intangible capital as the sum of Knowledge capital, which we estimate by accumulating past R\&D spending using the perpetual inventory method, and Organizational capital, which we estimate by accumulating a fraction (30\%) of past selling, general, and administrative (SG\&A) expenses using the same method. Externally purchased intangible capital is the balance sheet item Intangible Assets (intan). We scale Intangible capital by the book value of total assets (at). Each year, we define firms with above (below)median Intangible capital to total assets as high (low)-intangible capital-intensive. The last row reports the pvalues of the $F$-tests for differences in the coefficients on Investor_Stability for for each pair of subsamples. All regressions include year and industry fixed effects. All variables are defined in Appendix A. The $t$-statistics in parentheses are based on robust standard errors clustered at the firm level. ***, **, and * denote statistical significance at the $1 \%, 5 \%$, and $10 \%$ levels, respectively.

Panel A. R\&D intensity

\begin{tabular}{|c|c|c|c|c|c|c|}
\hline & \multicolumn{2}{|c|}{ Whole Sample } & \multicolumn{2}{|c|}{ Over-investment } & \multicolumn{2}{|c|}{ Under-investment } \\
\hline Variables & $\begin{array}{c}\text { High R\&D } \\
(1)\end{array}$ & $\begin{array}{c}\text { Low R\&D } \\
\text { (2) }\end{array}$ & $\begin{array}{c}\text { High R\&D } \\
\text { (3) }\end{array}$ & $\begin{array}{c}\text { Low R\&D } \\
(4)\end{array}$ & $\begin{array}{l}\text { High R\&D } \\
(5)\end{array}$ & $\begin{array}{c}\text { Low R\&D } \\
(6)\end{array}$ \\
\hline Investor_Stability t-1 & $\begin{array}{c}-0.146 * * * \\
(-5.56)\end{array}$ & $\begin{array}{c}-0.078 * * * \\
(-3.19)\end{array}$ & $\begin{array}{c}-0.198 * * * \\
(-4.35)\end{array}$ & $\begin{array}{c}-0.101 * * \\
(-2.55)\end{array}$ & $\begin{array}{c}-0.087 * * * \\
(-3.48)\end{array}$ & $\begin{array}{l}-0.025 \\
(-1.17)\end{array}$ \\
\hline Controls & Yes & Yes & Yes & Yes & Yes & Yes \\
\hline Year fixed effects & Yes & Yes & Yes & Yes & Yes & Yes \\
\hline Industry fixed effects & Yes & Yes & Yes & Yes & Yes & Yes \\
\hline Observations & 25,665 & 24,908 & 10,085 & 10,951 & 15,580 & 13,957 \\
\hline Adjusted $\mathrm{R}^{2}$ & 0.18 & 0.13 & 0.20 & 0.15 & 0.20 & 0.11 \\
\hline $\begin{array}{l}\text { p-value ( } F \text {-test of equal } \\
\text { coefficient estimates on } \\
\text { Investor_Stability) }\end{array}$ & $(0.05)$ & & $(0.10)$ & & $(0.06)$ & \\
\hline
\end{tabular}

Panel B. Intangible capital intensity

\begin{tabular}{|c|c|c|c|c|c|c|}
\hline & \multicolumn{2}{|c|}{ Whole Sample } & \multicolumn{2}{|c|}{ Over-investment } & \multicolumn{2}{|c|}{ Under-investment } \\
\hline Variables & $\begin{array}{l}\text { High IC } \\
\text { (1) }\end{array}$ & $\begin{array}{c}\text { Low IC } \\
\text { (2) }\end{array}$ & $\begin{array}{c}\text { High IC } \\
\text { (3) }\end{array}$ & $\begin{array}{c}\text { Low IC } \\
\text { (4) }\end{array}$ & $\begin{array}{l}\text { High IC } \\
\text { (5) }\end{array}$ & $\begin{array}{c}\text { Low IC } \\
\text { (6) }\end{array}$ \\
\hline Investor_Stability t-1 & $\begin{array}{c}-0.193 * * * \\
(-7.09)\end{array}$ & $\begin{array}{c}-0.072 * * * \\
(-3.17)\end{array}$ & $\begin{array}{c}-0.293 * * * \\
(-6.27)\end{array}$ & $\begin{array}{c}-0.077 * * \\
(-2.05)\end{array}$ & $\begin{array}{c}-0.098 * * * \\
(-3.66)\end{array}$ & $\begin{array}{c}-0.037 * \\
(-1.79)\end{array}$ \\
\hline Controls & Yes & Yes & Yes & Yes & Yes & Yes \\
\hline Year fixed effects & Yes & Yes & Yes & Yes & Yes & Yes \\
\hline Industry fixed effects & Yes & Yes & Yes & Yes & Yes & Yes \\
\hline Observations & 26,813 & 24,601 & 10,742 & 10,680 & 16,071 & 13,921 \\
\hline $\begin{array}{l}\text { Adjusted } \mathrm{R}^{2} \\
\text { p-value ( } F \text {-test of equal } \\
\text { coefficient estimates on } \\
\text { Investor_Stability) }\end{array}$ & $\begin{array}{c}0.18 \\
(0.00)\end{array}$ & 0.11 & $\begin{array}{c}0.22 \\
(0.00)\end{array}$ & 0.12 & $\begin{array}{c}0.15 \\
(0.07)\end{array}$ & 0.15 \\
\hline
\end{tabular}




\section{Table 7. Investor horizon and labor investment inefficiency: Cross-sectional variation}

Panel A (B) examines the relation between investor horizon and under- (over-) investment in labor for subsamples of firms with different characteristics. Over-investing firms are defined as those with positive abnormal net hiring. Under-investing firms are defined as those with negative abnormal net hiring. In Models 1 and 2 , we examine firms with a high degree of complexity versus firms with a low degree of complexity. Firm complexity is a dummy variable set equal to one if a firm has more than two business segments, and zero otherwise. In Models 3 and 4, we present the results for firms with varying degrees of corporate governance quality. We proxy for corporate governance quality using Cain et al.'s (2017) takeover index. Firms with above-median (below-median) takeover index are defined as high (low) governance quality firms. In Models 5 and 6, we present the results for firms with varying degrees of financial reporting quality. Firms with above-median (below-median) accounting quality are defined as high (low) reporting quality firms. Accounting Quality is defined in Appendix A. In Models 7 and 8, we present the results for firms with below-median (above-median) short-term debt. Short-term debt is the ratio of debt due in the next three years to total debt $((\mathrm{dlc}+\mathrm{dd} 2+\mathrm{dd} 3) /(\mathrm{dltt}+\mathrm{dlc}))$. In Models 9 and 10 , we present the results for firms with male versus female CEOs. In Models 11 and 12, we present the results for firms with old (above-median age) versus young (below-median age) CEOs. In Models 13 and 14, we report the results for high (above-median) and low (below-median) managerial ownership, defined as the value of the CEO's stock and option portfolio (based on Daniel et al., 2019). The last row reports the p-values of the $F$-tests for differences in the coefficients on Investor_Stability for the two subsamples being compared. All regressions include year and industry fixed effects. The $t$-statistics in parentheses are based on robust standard errors clustered at the firm level. ***, **, and * denote significance at the $1 \%, 5 \%$, and $10 \%$ levels.

\section{Panel A. Monitoring under-investment in labor: Cross-sectional variation}

\begin{tabular}{|c|c|c|c|c|c|c|c|c|c|c|c|c|c|c|}
\hline \multirow[b]{2}{*}{ Variables } & \multicolumn{2}{|c|}{$\begin{array}{c}\text { Firm } \\
\text { complexity }\end{array}$} & \multicolumn{2}{|c|}{$\begin{array}{c}\text { Corporate } \\
\text { governance quality }\end{array}$} & \multicolumn{2}{|c|}{$\begin{array}{c}\text { Financial } \\
\text { reporting quality }\end{array}$} & \multicolumn{2}{|c|}{$\begin{array}{c}\text { Debt } \\
\text { maturity }\end{array}$} & \multicolumn{2}{|c|}{$\begin{array}{l}\text { CEO } \\
\text { gender }\end{array}$} & \multicolumn{2}{|c|}{$\begin{array}{l}\text { CEO } \\
\text { age }\end{array}$} & \multicolumn{2}{|c|}{$\begin{array}{l}\text { Managerial } \\
\text { Ownership }\end{array}$} \\
\hline & $\begin{array}{l}\text { High } \\
\text { (1) }\end{array}$ & $\begin{array}{c}\text { Low } \\
(2)\end{array}$ & $\begin{array}{l}\text { High } \\
(3)\end{array}$ & $\begin{array}{c}\text { Low } \\
(4)\end{array}$ & $\begin{array}{l}\text { High } \\
(5)\end{array}$ & $\begin{array}{c}\text { Low } \\
(6)\end{array}$ & $\begin{array}{l}\text { Long } \\
(7)\end{array}$ & $\begin{array}{c}\text { Short } \\
(8)\end{array}$ & $\begin{array}{l}\text { Male } \\
(9)\end{array}$ & $\begin{array}{c}\text { Female } \\
(10)\end{array}$ & $\begin{array}{l}\text { Old } \\
(11)\end{array}$ & $\begin{array}{l}\text { Young } \\
(12)\end{array}$ & $\begin{array}{l}\text { High } \\
(13)\end{array}$ & $\begin{array}{l}\text { Low } \\
(14)\end{array}$ \\
\hline Investor_Stability $\mathrm{t}-1$ & $\begin{array}{c}-0.124 * * * \\
(-5.30)\end{array}$ & $\begin{array}{l}-0.006 \\
(-0.23)\end{array}$ & $\begin{array}{l}0.039 \\
(1.07)\end{array}$ & $\begin{array}{c}-0.103^{* *} \\
(-2.29)\end{array}$ & $\begin{array}{l}0.004 \\
(0.14)\end{array}$ & $\begin{array}{c}-0.093 * * \\
(-2.15)\end{array}$ & $\begin{array}{l}-0.024 \\
(-0.99)\end{array}$ & $\begin{array}{c}-0.092 * * * \\
(-3.86)\end{array}$ & $\begin{array}{l}-0.016 \\
(-0.40)\end{array}$ & $\begin{array}{l}-0.139 \\
(-1.00)\end{array}$ & $\begin{array}{c}-0.150 * * \\
(-1.96)\end{array}$ & $\begin{array}{l}0.049 \\
(1.07)\end{array}$ & $\begin{array}{l}-0.023 \\
(-0.55)\end{array}$ & $\begin{array}{c}-0.120 * * * \\
(-3.03)\end{array}$ \\
\hline Controls & Yes & Yes & Yes & Yes & Yes & Yes & Yes & Yes & Yes & Yes & Yes & Yes & Yes & Yes \\
\hline Year \& industry FE & Yes & Yes & Yes & Yes & Yes & Yes & Yes & Yes & Yes & Yes & Yes & Yes & Yes & Yes \\
\hline Observations & 16,845 & 11,860 & 12,131 & 12,009 & 8,502 & 8,152 & 12,947 & 12,727 & 5,337 & 217 & 2,256 & 2,304 & 4,972 & 5,064 \\
\hline $\begin{array}{l}\text { Adjusted } \mathrm{R}^{2} \\
\text { p-value ( } F \text {-test })\end{array}$ & $\begin{array}{c}0.17 \\
(0.00)\end{array}$ & 0.16 & $\begin{array}{c}0.13 \\
(0.01)\end{array}$ & 0.18 & $\begin{array}{c}0.11 \\
(0.06)\end{array}$ & 0.16 & $\begin{array}{c}0.14 \\
(0.04)\end{array}$ & 0.16 & $\begin{array}{c}0.13 \\
(0.39)\end{array}$ & 0.18 & $\begin{array}{c}0.14 \\
(0.03)\end{array}$ & 0.13 & $\begin{array}{c}0.13 \\
(0.08)\end{array}$ & 0.11 \\
\hline
\end{tabular}


Panel B. Monitoring over-investment in labor: Cross-sectional variation

\begin{tabular}{|c|c|c|c|c|c|c|c|c|c|c|c|c|c|c|}
\hline \multirow[b]{2}{*}{ Variables } & \multicolumn{2}{|c|}{$\begin{array}{c}\text { Firm } \\
\text { complexity }\end{array}$} & \multicolumn{2}{|c|}{$\begin{array}{c}\text { Corporate } \\
\text { governance quality }\end{array}$} & \multicolumn{2}{|c|}{$\begin{array}{c}\text { Financial } \\
\text { reporting quality }\end{array}$} & \multicolumn{2}{|c|}{$\begin{array}{c}\text { Debt } \\
\text { maturity }\end{array}$} & \multicolumn{2}{|c|}{$\begin{array}{l}\text { CEO } \\
\text { gender }\end{array}$} & \multicolumn{2}{|c|}{$\begin{array}{l}\text { CEO } \\
\text { age }\end{array}$} & \multicolumn{2}{|c|}{$\begin{array}{l}\text { Managerial } \\
\text { Ownership }\end{array}$} \\
\hline & $\begin{array}{l}\text { High } \\
(1)\end{array}$ & $\begin{array}{c}\text { Low } \\
(2)\end{array}$ & $\begin{array}{l}\text { High } \\
(3)\end{array}$ & $\begin{array}{c}\text { Low } \\
(4)\end{array}$ & $\begin{array}{l}\text { High } \\
\text { (5) }\end{array}$ & $\begin{array}{c}\text { Low } \\
(6)\end{array}$ & $\begin{array}{l}\text { Long } \\
(7)\end{array}$ & $\begin{array}{c}\text { Short } \\
(8)\end{array}$ & $\begin{array}{l}\text { Male } \\
(9)\end{array}$ & $\begin{array}{c}\text { Female } \\
(10)\end{array}$ & $\begin{array}{l}\text { Old } \\
(11)\end{array}$ & $\begin{array}{c}\text { Young } \\
(12)\end{array}$ & $\begin{array}{l}\text { High } \\
(13)\end{array}$ & $\begin{array}{l}\text { Low } \\
(14) \\
\end{array}$ \\
\hline Investor_Stability ${ }_{\mathrm{t}-1}$ & $\begin{array}{c}-0.266 * * * \\
(-5.89)\end{array}$ & $\begin{array}{l}-0.008 \\
(-0.19)\end{array}$ & $\begin{array}{c}-0.116 * * \\
(-2.83)\end{array}$ & $\begin{array}{c}-0.133 * * * \\
(-3.00)\end{array}$ & $\begin{array}{l}-0.005 \\
(-0.08)\end{array}$ & $\begin{array}{c}-0.202 * * * \\
(-3.14)\end{array}$ & $\begin{array}{c}-0.153 * * * \\
(-3.08)\end{array}$ & $\begin{array}{c}-0.087 * * \\
(-2.13)\end{array}$ & $\begin{array}{c}-1.775 * * * \\
(-3.04)\end{array}$ & $\begin{array}{c}-0.313 * * * \\
(-3.38)\end{array}$ & $\begin{array}{c}-0.454 * * * \\
(-2.97)\end{array}$ & $\begin{array}{c}-0.185 * \\
(-1.81)\end{array}$ & $\begin{array}{c}-0.377 * * * \\
(-3.73)\end{array}$ & $\begin{array}{l}-0.152 * \\
(-1.85)\end{array}$ \\
\hline Controls & Yes & Yes & Yes & Yes & Yes & Yes & Yes & Yes & Yes & Yes & Yes & Yes & Yes & Yes \\
\hline Year \& industry FE & Yes & Yes & Yes & Yes & Yes & Yes & Yes & Yes & Yes & Yes & Yes & Yes & Yes & Yes \\
\hline Observations & 11,762 & 8,857 & 9,998 & 10,376 & 5,590 & 5,637 & 9,680 & 9,236 & 3,854 & 128 & 1,720 & 1,805 & 3,743 & 3,331 \\
\hline $\begin{array}{l}\text { Adjusted } \mathrm{R}^{2} \\
\text { p-value }(F \text {-test })\end{array}$ & $\begin{array}{c}0.17 \\
(0.00)\end{array}$ & 0.17 & $\begin{array}{c}0.16 \\
(0.77)\end{array}$ & 0.17 & $\begin{array}{c}0.16 \\
(0.03)\end{array}$ & 0.17 & $\begin{array}{c}0.22 \\
(0.31)\end{array}$ & 0.14 & $\begin{array}{c}0.18 \\
(0.01)\end{array}$ & 0.07 & $\begin{array}{c}0.19 \\
(0.14)\end{array}$ & 0.18 & $\begin{array}{c}0.17 \\
(0.08)\end{array}$ & 0.19 \\
\hline
\end{tabular}




\section{Table 8. Expected net hiring: Robustness tests and alternative proxies}

This table presents the results of robustness tests in which we replicate our main analysis using several alternative estimations of the Pinnuck and Lillis (2007) (P\&L) model (Panels A and B), and alternative measures of expected net hiring (Panel C). In all models, we regress Abnormal_Net_Hiring on Investor_Stability and the control variables. In Model 1 of Panel A, we estimate expected net hiring using the P\&L model with industry and year fixed effects. In Model 2, we estimate expected net hiring using the P\&L model after adding time effects and replacing the industry dummies with firm fixed effects. In Model 3, we estimate expected net hiring using the P\&L model controlling for firm, industry-year, and state-year fixed effects. In Model 4, we estimate expected net hiring using the $\mathrm{P} \& \mathrm{~L}$ model controlling for year, firm, and state fixed effects as well as eight additional controls. In particular, we control for (a) capital expenditures measured as the ratio of capital expenditures (capx) to total assets (at); (b) R\&D expenditures measured as the ratio of R\&D expenses (xrd) to net sales (sale), and is set equal to zero when R\&D expenses (xrd) are missing; (c) Acquisitions measured as the ratio of acquisitions (aqc) to total assets (at); (d) Institutional ownership; (e) Payout ratio defined as the ratio of common dividends (dvc) to total assets (at); (f) corporate governance quality measured by Cain et al.'s (2017) takeover index; (g) WDL, which captures the time-variant state-level recognition of wrongful discharge laws (Serfling, 2016); and (h) future industry sales growth, which captures the forward-looking prospects of the industry where a firm operates. All the covariates in Model 4 are included in both lagged and contemporaneous forms. In Model 5, we interact all the covariates in the original P\&L model with institutional ownership. In Model 6, we apply the methodology proposed by Chen et al. (2018) to deal with potential bias in the two-stage estimation. Specifically, we include all the covariates from the first-stage estimation of the P\&L model in our second stage. In Panel B, we estimate expected net hiring using the P\&L model separately for firms facing high labor adjustment costs (LACs) versus firms facing low LACs. We proxy for LACs using firms' reliance on skilled labor (Labor_Skill). For each year, we define firms in the top (bottom) $30^{\text {th }}$ percentile of Labor_Skill as high (low) LACs firms. In Panel C, we use alternative measures of expected net hiring that do not rely on the P\&L model. In Model 1, we estimate expected net hiring using the median investment in the firm's industry. Industries are defined using the Fama-French (1997) 48-industry classification. In Model 2, we measure expected net hiring using the firm's average investment in the previous three years. All regressions for the second stage include year and industry fixed effects. All the other variables are defined in Appendix A. The $t$-statistics in parentheses are based on robust standard errors clustered at the firm level. $* * *, * *$, and $*$ denote statistical significance at the $1 \%, 5 \%$, and $10 \%$ levels, respectively.

\section{Panel A. Pinnuck and Lillis model: Robustness tests}

\begin{tabular}{|c|c|c|c|c|c|c|}
\hline Variables & $\begin{array}{c}\text { P\&L model } \\
\text { with } \\
\text { industry } \\
\text { and year } \\
\text { fixed } \\
\text { effects } \\
\text { (1) }\end{array}$ & $\begin{array}{l}\text { P\&L model } \\
\text { with firm } \\
\text { and year } \\
\text { fixed } \\
\text { effects }\end{array}$ & $\begin{array}{l}\text { P\&L model } \\
\text { with firm, } \\
\text { industry- } \\
\text { year, and } \\
\text { state-year } \\
\text { fixed } \\
\text { effects } \\
\text { (3) }\end{array}$ & $\begin{array}{l}\text { P\&L model } \\
\text { with firm, } \\
\text { year, and } \\
\text { state fixed } \\
\text { effects, \& } \\
\text { additional } \\
\text { controls } \\
\text { (4) }\end{array}$ & $\begin{array}{l}\text { P\&L model } \\
\text { with all } \\
\text { covariates } \\
\text { interacted } \\
\text { with } \\
\text { institutional } \\
\text { ownership } \\
\text { (5) }\end{array}$ & $\begin{array}{l}\text { P\&L model } \\
\text { with all } \\
\text { covariates } \\
\text { from } 1^{\text {st }} \\
\text { stage } \\
\text { included in } \\
2^{\text {nd }} \text { stage } \\
(6)\end{array}$ \\
\hline Investor_Stability t-1 & $\begin{array}{c}-0.102 * * * \\
(-5.73)\end{array}$ & $\begin{array}{c}-0.094 * * * \\
(-5.40)\end{array}$ & $\begin{array}{c}-0.081 * * * \\
(-4.69)\end{array}$ & $\begin{array}{c}-0.092 * * * \\
(-4.98)\end{array}$ & $\begin{array}{c}-0.104 * * * \\
(-5.77)\end{array}$ & $\begin{array}{c}-0.060 * * * \\
(-3.52)\end{array}$ \\
\hline Controls & Yes & Yes & Yes & Yes & Yes & Yes \\
\hline Year fixed effects & Yes & Yes & Yes & Yes & Yes & Yes \\
\hline Industry fixed effects & Yes & Yes & Yes & Yes & Yes & Yes \\
\hline Observations & 51,414 & 51,414 & 51,414 & 42,619 & 51,414 & 51,414 \\
\hline Adjusted $R^{2}: 1^{\text {st }}$ stage & 0.23 & 0.28 & 0.28 & 0.38 & 0.24 & 0.23 \\
\hline Adjusted $\mathrm{R}^{2}: 2^{\text {nd }}$ stage & 0.15 & 0.15 & 0.15 & 0.12 & 0.15 & 0.21 \\
\hline
\end{tabular}


Panel B. Pinnuck and Lillis model: Subsamples with different LACs

\begin{tabular}{|c|c|c|c|c|c|c|}
\hline & \multicolumn{2}{|c|}{ Whole Sample } & \multicolumn{2}{|c|}{ Over-investment } & \multicolumn{2}{|c|}{ Under-investment } \\
\hline Variables & $\begin{array}{l}\text { High } \\
\text { LACs } \\
(1)\end{array}$ & $\begin{array}{l}\text { Low } \\
\text { LACs } \\
(2)\end{array}$ & $\begin{array}{l}\text { High } \\
\text { LACs } \\
(3)\end{array}$ & $\begin{array}{l}\text { Low } \\
\text { LACs } \\
(4)\end{array}$ & $\begin{array}{l}\text { High } \\
\text { LACs } \\
(5)\end{array}$ & $\begin{array}{c}\text { Low LACs } \\
\text { (6) }\end{array}$ \\
\hline Investor_Stability t-1 & $\begin{array}{c}-0.224 * * \\
(-4.07)\end{array}$ & $\begin{array}{c}-0.099 * * \\
(-2.34)\end{array}$ & $\begin{array}{c}-0.321 * * * \\
(-3.31)\end{array}$ & $\begin{array}{l}-0.039 \\
(-0.57)\end{array}$ & $\begin{array}{c}-0.116^{* * * *} \\
(-2.61)\end{array}$ & $\begin{array}{c}-0.094 * * * \\
(-2.64)\end{array}$ \\
\hline Controls & Yes & Yes & Yes & Yes & Yes & Yes \\
\hline Year fixed effects & Yes & Yes & Yes & Yes & Yes & Yes \\
\hline Industry fixed effects & Yes & Yes & Yes & Yes & Yes & Yes \\
\hline Observations & 6,502 & 7,515 & 2,822 & 3,072 & 3,675 & 4,443 \\
\hline $\begin{array}{l}\text { Adjusted } \mathrm{R}^{2} \\
\text { p-value ( } F \text {-test of equal } \\
\text { coefficient estimates on } \\
\text { Investor_Stability) }\end{array}$ & $\begin{array}{c}0.16 \\
(0.07)\end{array}$ & 0.15 & $\begin{array}{c}0.18 \\
(0.02)\end{array}$ & 0.17 & $\begin{array}{c}0.19 \\
(0.70)\end{array}$ & 0.15 \\
\hline
\end{tabular}

Panel C. Alternative proxies

\begin{tabular}{lcc}
\hline Variables & $\begin{array}{c}\text { Expected Net Hiring } \\
=\text { industry median } \\
\end{array}$ & $\begin{array}{c}\text { Expected Net Hiring } \\
\text { average in past 3 years } \\
(2)\end{array}$ \\
\hline Investor_Stability t-1 & $-0.118^{* * *}$ & $-0.100^{* * *}$ \\
& $(-6.06)$ & $(-3.53)$ \\
\hline Controls & \multicolumn{2}{|c}{} \\
Year fixed effects & Yes & Yes \\
Industry fixed effects & Yes & Yes \\
Observations & Yes & Yes \\
Adjusted R ${ }^{2}$ & 51,414 & 26,882 \\
\end{tabular}




\section{Table 9. Controlling for alternative explanations}

This table reports the regression results on the impact of institutional investment horizons on abnormal net hiring, controlling for various firm-level corporate governance variables (Panel A) and variables that have been shown by previous papers to be related to investor horizon (Panel B). G-index is the Gompers et al. (2003) corporate governance index of 24 antitakeover provisions. E-index is the Bebchuck et al. (2009) managerial entrenchment index. Takeover Index is the Cain et al. (2017) takeover index. Direct_Own is the natural log of the dollar value of common stock owned by the median director. Ind_Director is the percentage of board members classified as independent. CEO Duality is an indicator variable that takes the value of one if the CEO of the sample firm is also the board chair, and zero otherwise. Blockholdings is the number of institutions whose ownership is at least 5\% of the firm's outstanding shares. For non-labor investments, we control for capital expenditures, R\&D expenditures, and acquisitions. Cost of capital is the implied cost of capital estimated following Lau et al. (2010). Financial constraints is proxied using the Kaplan and Zingales (1997) (KZ) index. CSR is corporate social responsibility, which is measured using KLD data following Nguyen et al. (2020). Equity issues is the ratio of equity issues (sstk) to total assets. In Panel A, Models 1-7 control separately for each governance variable. Model 8 controls for all the governance variables. In Panel B, Models 1-7 control separately for each variable. Model 8 controls for all the variables in Panels A and B with a comparable number of non-missing observations to the main sample; these include the takeover index, blockholdings, non-labor investments, financial reporting quality, managerial ability, equity issues, and financial constraints. Model 9 controls for all the variables in Panels A and B. All the other variables are defined in Appendix A. The $t$-statistics in parentheses are based on robust standard errors clustered at the firm level. ***,**, and * denote statistical significance at the $1 \%, 5 \%$, and $10 \%$ levels, respectively.

\section{Panel A. Corporate governance controls}

\begin{tabular}{|c|c|c|c|c|c|c|c|c|}
\hline Variables & $\begin{array}{c}\text { G-index } \\
\text { (1) }\end{array}$ & $\begin{array}{c}\text { E-index } \\
\text { (2) }\end{array}$ & $\begin{array}{l}\text { Takeover } \\
\text { Index } \\
(3)\end{array}$ & $\begin{array}{c}\text { Direct_- } \\
\text { Own } \\
(4)\end{array}$ & $\begin{array}{l}\text { Ind_- } \\
\text { Director } \\
\text { (5) }\end{array}$ & $\begin{array}{c}\text { CEO } \\
\text { Duality } \\
\text { (6) }\end{array}$ & $\begin{array}{c}\text { Block } \\
\text { holdings } \\
(7)\end{array}$ & $\begin{array}{c}\text { All } \\
\text { controls } \\
(8)\end{array}$ \\
\hline Investor_Stability t-1 & $\begin{array}{c}-0.176 * * * \\
(-3.05)\end{array}$ & $\begin{array}{c}-0.178 * * * \\
(-3.05)\end{array}$ & $\begin{array}{c}-0.100 * * * \\
(-5.34)\end{array}$ & $\begin{array}{c}-0.158 * * * \\
(-2.82)\end{array}$ & $\begin{array}{c}-0.171 * * * \\
(-3.06)\end{array}$ & $\begin{array}{c}-0.170 * * * \\
(-3.04)\end{array}$ & $\begin{array}{c}-0.089 * * * \\
(-4.68)\end{array}$ & $\begin{array}{c}-0.129 * * \\
(-2.14)\end{array}$ \\
\hline Controls & Yes & Yes & Yes & Yes & Yes & Yes & Yes & Yes \\
\hline Year fixed effects & Yes & Yes & Yes & Yes & Yes & Yes & Yes & Yes \\
\hline Industry fixed effects & Yes & Yes & Yes & Yes & Yes & Yes & Yes & Yes \\
\hline Observations & 5,883 & 5,883 & 49,515 & 6,146 & 6,304 & 6,331 & 46,019 & 5,682 \\
\hline Adjusted $\mathrm{R}^{2}$ & 0.14 & 0.14 & 0.15 & 0.14 & 0.15 & 0.15 & 0.14 & 0.15 \\
\hline
\end{tabular}

Panel B. Additional controls

\begin{tabular}{|c|c|c|c|c|c|c|c|c|c|}
\hline Variables & $\begin{array}{c}\text { Non-labor } \\
\text { inv. }\end{array}$ & $\begin{array}{l}\text { Fin. } \\
\text { reporting } \\
\text { quality }\end{array}$ & $\begin{array}{l}\text { Man. } \\
\text { ability }\end{array}$ & $\begin{array}{c}\text { Cost } \\
\text { of capital }\end{array}$ & $\begin{array}{c}\text { Financial } \\
\text { constraints }\end{array}$ & CSR & $\begin{array}{l}\text { Equity } \\
\text { issues }\end{array}$ & $\begin{array}{c}\text { All } \\
\text { controls } \\
\text { (large } \\
\text { sample) } \\
(8)\end{array}$ & $\begin{array}{c}\text { All } \\
\text { controls } \\
\text { from } \\
\text { Panels A } \\
\text { \& B } \\
\text { (9) }\end{array}$ \\
\hline Investor_Stability t-1 & $\begin{array}{c}-0.106 * * * \\
(-5.87)\end{array}$ & $\begin{array}{c}-0.090 * * * \\
(-3.51)\end{array}$ & $\begin{array}{c}-0.091 * * * \\
(-5.41)\end{array}$ & $\begin{array}{c}-0.166^{* * * *} \\
(-2.54)\end{array}$ & $\begin{array}{c}-0.103 * * * \\
(-5.67)\end{array}$ & $\begin{array}{c}-0.234 * * * \\
(-3.33)\end{array}$ & $\begin{array}{c}-0.090 * * * \\
(-4.99)\end{array}$ & $\begin{array}{c}-0.068 * * * \\
(-3.54)\end{array}$ & $\begin{array}{c}-0.203^{*} \\
(-1.69)\end{array}$ \\
\hline Controls & Yes & Yes & Yes & Yes & Yes & Yes & Yes & Yes & Yes \\
\hline Year fixed effects & Yes & Yes & Yes & Yes & Yes & Yes & Yes & Yes & Yes \\
\hline Industry fixed effects & Yes & Yes & Yes & Yes & Yes & Yes & Yes & Yes & Yes \\
\hline Observations & 51,003 & 43,896 & 50,898 & 5,472 & 50,211 & 5,400 & 50,288 & 42,479 & 1,405 \\
\hline Adjusted $\mathrm{R}^{2}$ & 0.15 & 0.15 & 0.14 & 0.15 & 0.15 & 0.18 & 0.15 & 0.14 & 0.19 \\
\hline
\end{tabular}




\section{Table 10. Identification strategy: The reconstitution of Russell indexes}

This table reports the results from instrumental variable (IV) regressions using two-stage least squares (2SLS) estimations. The dependent variable in the first stage is the change in quasi-indexer ownership (AQuasi-indexer Ownership), which is calculated as the annual change in the fraction of shares held by quasi-indexer institutional investors in a firm, measured at the end of the first quarter after the reconstitution. The first two instruments for $\Delta$ Quasi-indexer Ownership are indicator variables equal to one if a stock switches from the Russell 1000 index to the Russell 2000 index $\left(R 1000_{t-1} \rightarrow R 200{ }_{t}\right)$ or the Russell 2000 index to the Russell 1000 index $\left(R 2000_{t-1} \rightarrow\right.$ $\left.R 1000_{t}\right)$ at the annual Russell index reconstitution. The third instrument tracks the change in index rank from one year to another $\left(\operatorname{Rank}_{t}-\operatorname{Rank}_{t-1}\right)$. The regressions in the second stage include the fitted values of $\Delta$ Quasi-indexer Ownership as well as all the control variables included in the first-stage regressions. The dependent variable in the second stage is the annual change in abnormal net hiring ( $\triangle A$ Abnormal_Net_Hiring). The IV regressions focus only on switchers around the threshold. The first regression includes firms that, in a given year, switched by at most 200 ranks between the two Russell indexes, whereas the second regression focuses only on firms that switched by at most 100 ranks. All regressions include year and industry fixed effects. In Panel A, we report the results using the same set of controls as in Schmidt and Fahlenbrach (2017). In Panel B, we also include the controls from our baseline specification (Eq. (6)) and the float adjusted market cap. End-of-May Market Cap is CRSP price (prc) multiplied by number of shares outstanding (shrout). Float Adjustment is the difference between the rank implied by the observed end-of-May CRSP market capitalization and the rank assigned by Russell in June (Crane et al., 2016). All the other variables are defined in Appendix A. F-statistic is the statistic from the Ftest of the joint significance of the instruments in the first-stage regressions. $J$-statistic (p-value) is the p-value from the Hansen $(\mathrm{J})$ test of instrument overidentification. The $t$-statistics in parentheses are based on robust standard errors clustered at the firm level. ***,**, and * denote statistical significance at the $1 \%, 5 \%$, and $10 \%$ levels, respectively.

Panel A. Without original controls

\begin{tabular}{|c|c|c|c|c|}
\hline \multirow{3}{*}{ Variables } & \multicolumn{4}{|c|}{ Dependent variable in $2^{\text {nd }}$ stage: $\Delta$ Abnormal_Net_Hiring $t$} \\
\hline & \multicolumn{2}{|c|}{$\begin{array}{l}\text { Switchers around } \\
\text { the threshold } \\
\text { (at most } 200 \text { ranks) }\end{array}$} & \multicolumn{2}{|c|}{$\begin{array}{l}\text { Switchers around } \\
\text { the threshold } \\
\text { (at most } 100 \text { ranks) }\end{array}$} \\
\hline & $1^{\text {st }}$ Stage & $2^{\text {nd }}$ Stage & $1^{\text {st }}$ Stage & $2^{\text {nd }}$ Stage \\
\hline$\Delta$ Quasi-indexer Ownership $_{\mathrm{t}}$ & & $\begin{array}{c}-2.461 * * * \\
(-4.25)\end{array}$ & & $\begin{array}{c}-2.525 * * * \\
(-4.37)\end{array}$ \\
\hline $\mathrm{R} 1000_{\mathrm{t}-1} \rightarrow \mathrm{R} 2000_{\mathrm{t}}$ & $\begin{array}{c}0.015 * * * \\
(3.06)\end{array}$ & & $\begin{array}{c}0.036 * * * \\
(3.71)\end{array}$ & \\
\hline $\mathrm{R} 2000_{\mathrm{t}-1} \rightarrow \mathrm{R} 1000_{\mathrm{t}}$ & $\begin{array}{c}-0.015 * * * \\
(-3.13)\end{array}$ & & $\begin{array}{c}-0.021 * * \\
(-2.54)\end{array}$ & \\
\hline $\operatorname{Rank}_{\mathrm{t}}-$ Rank $_{\mathrm{t}-1}$ & $\begin{array}{c}-0.002 * * * \\
(-7.11)\end{array}$ & & $\begin{array}{c}-0.002 * * * \\
(-7.08)\end{array}$ & \\
\hline End-of-May Market Cap ${ }_{t-1}$ & $\begin{array}{c}-0.004 * * * \\
(-13.94)\end{array}$ & $\begin{array}{c}-0.005 * * \\
(-2.30)\end{array}$ & $\begin{array}{c}-0.004 * * * \\
(-13.90)\end{array}$ & $\begin{array}{c}-0.005^{* *} \\
(-2.42)\end{array}$ \\
\hline Return $_{\mathrm{t}}$ & $\begin{array}{c}-0.003 * * * \\
(-3.03)\end{array}$ & $\begin{array}{l}-0.004 \\
(-0.59)\end{array}$ & $\begin{array}{c}-0.003 * * * \\
(-2.99)\end{array}$ & $\begin{array}{l}-0.003 \\
(-0.54)\end{array}$ \\
\hline Return $\mathrm{t}-1$ & $\begin{array}{c}-0.008 * * * \\
(-5.56)\end{array}$ & $\begin{array}{c}-0.035^{* * *} * \\
(-5.22)\end{array}$ & $\begin{array}{c}-0.008 * * * \\
(-5.52)\end{array}$ & $\begin{array}{c}-0.035 * * * \\
(-5.23)\end{array}$ \\
\hline $\mathrm{ROA}_{\mathrm{t}-1}$ & $\begin{array}{c}0.012 * * * \\
(3.01)\end{array}$ & $\begin{array}{c}-0.099 * * * \\
(-4.09)\end{array}$ & $\begin{array}{c}0.012 * * * \\
(3.11)\end{array}$ & $\begin{array}{c}-0.097 * * * \\
(-3.96)\end{array}$ \\
\hline$\Delta$ Size & $\begin{array}{c}0.017 * * * \\
(6.77)\end{array}$ & $\begin{array}{c}0.307 * * * \\
(13.14) \\
\end{array}$ & $\begin{array}{c}0.017 * * * \\
(6.77)\end{array}$ & $\begin{array}{c}0.305^{* * *} * \\
(13.03)\end{array}$ \\
\hline Original controls & No & No & No & No \\
\hline Year fixed effects & Yes & Yes & Yes & Yes \\
\hline Industry fixed effects & Yes & Yes & Yes & Yes \\
\hline Observations & 18,980 & 18,980 & 18,745 & 18,745 \\
\hline$F$-statistic & 21.45 & & 23.22 & \\
\hline$J$-statistic (p-value) & 0.16 & & 0.31 & \\
\hline
\end{tabular}


Panel B. With original controls

\begin{tabular}{|c|c|c|c|c|}
\hline \multirow{3}{*}{ Variables } & \multicolumn{4}{|c|}{ Dependent variable in $2^{\text {nd }}$ stage: $\Delta$ Abnormal_Net_Hiring $\mathrm{t}$} \\
\hline & \multicolumn{2}{|c|}{$\begin{array}{c}\text { Switchers around } \\
\text { the threshold } \\
\text { (at most } 200 \text { ranks) }\end{array}$} & \multicolumn{2}{|c|}{$\begin{array}{l}\text { Switchers around } \\
\text { the threshold } \\
\text { (at most } 100 \text { ranks) }\end{array}$} \\
\hline & $1^{\text {st }}$ Stage & $2^{\text {nd }}$ Stage & $1^{\text {st }}$ Stage & $2^{\text {nd }}$ Stage \\
\hline$\Delta$ Quasi-indexer Ownership ${ }_{\mathrm{t}}$ & & $\begin{array}{c}-2.222 * * * \\
(-3.03)\end{array}$ & & $\begin{array}{c}-2.782 * * * \\
(-3.40)\end{array}$ \\
\hline $\mathrm{R} 1000_{t-1} \rightarrow \mathrm{R} 2000_{t}$ & $\begin{array}{c}0.016^{* * * *} \\
(3.30)\end{array}$ & & $\begin{array}{c}0.034 * * * \\
(3.37)\end{array}$ & \\
\hline $\mathrm{R} 2000_{\mathrm{t}-1} \rightarrow \mathrm{R} 1000_{\mathrm{t}}$ & $\begin{array}{c}-0.016 * * * \\
(-3.10)\end{array}$ & & $\begin{array}{c}-0.021 * * \\
(-2.42)\end{array}$ & \\
\hline $\operatorname{Rank}_{t}-\operatorname{Rank}_{t-1}$ & $\begin{array}{c}-0.001 * * * \\
(-4.60)\end{array}$ & & $\begin{array}{c}-0.001 * * * \\
(-4.57)\end{array}$ & \\
\hline End-of-May Market Cap t-1 & $\begin{array}{c}-0.003 * * * \\
(-8.59)\end{array}$ & $\begin{array}{c}-0.004 * * \\
(-2.03)\end{array}$ & $\begin{array}{c}-0.003 * * * \\
(-8.53)\end{array}$ & $\begin{array}{c}-0.006 * * \\
(-2.46)\end{array}$ \\
\hline Return $_{\mathrm{t}}$ & $\begin{array}{c}-0.002 * \\
(-1.84)\end{array}$ & $\begin{array}{l}0.002 \\
(0.26)\end{array}$ & $\begin{array}{c}-0.002 * \\
(-1.83)\end{array}$ & $\begin{array}{l}0.000 \\
(0.06)\end{array}$ \\
\hline Return $_{\mathrm{t}-1}$ & $\begin{array}{c}-0.008 * * * \\
(-5.01)\end{array}$ & $\begin{array}{c}-0.036 * * * \\
(-4.85)\end{array}$ & $\begin{array}{c}-0.008 * * * \\
(-4.96)\end{array}$ & $\begin{array}{c}-0.040 * * * \\
(-4.83)\end{array}$ \\
\hline $\mathrm{ROA}_{\mathrm{t}-1}$ & $\begin{array}{c}0.028 * * * \\
(4.99)\end{array}$ & $\begin{array}{l}0.017 \\
(0.44)\end{array}$ & $\begin{array}{c}0.028 * * * \\
(4.88)\end{array}$ & $\begin{array}{l}0.033 \\
(0.80)\end{array}$ \\
\hline$\Delta$ Size & $\begin{array}{l}0.015 * * * \\
(5.22)\end{array}$ & $\begin{array}{c}0.236 * * * \\
(9.62)\end{array}$ & $\begin{array}{c}0.016 * * * \\
(5.26)\end{array}$ & $\begin{array}{c}0.244 * * * \\
(9.32)\end{array}$ \\
\hline Float Adjustment ${ }_{t-1}$ & $\begin{array}{c}0.000 \\
(0.63) \\
\end{array}$ & $\begin{array}{l}-0.000 \\
(-0.30)\end{array}$ & $\begin{array}{c}0.000 \\
(0.74) \\
\end{array}$ & $\begin{array}{c}-0.000 \\
(-0.09) \\
\end{array}$ \\
\hline Original controls & Yes & Yes & Yes & Yes \\
\hline Year fixed effects & Yes & Yes & Yes & Yes \\
\hline Industry fixed effects & Yes & Yes & Yes & Yes \\
\hline Observations & 17,034 & 17,034 & 16,815 & 16,815 \\
\hline$F$-statistic & 12.41 & & 12.56 & \\
\hline$J$-statistic (p-value) & 0.10 & & 0.55 & \\
\hline
\end{tabular}




\section{Table 11. The impact of short-term investors}

This table reports the results for the separate effects of short- and long-term ownership on abnormal net hiring. We present the results for the whole sample in Model 1. In Models 2 and 3, we present the results for the subsamples of over- and under-investing firms, respectively. In all models, we regress Abnormal_Net_Hiring on short-term ownership, long-term ownership, and the control variables. Short-term ownership is measured as the percentage of shares owned by transient institutional investors based on Bushee (1998). Long-term ownership is measured as the percentage of shares owned by dedicated and quasi-indexed institutional investors based on Bushee (1998). In Models 4 and 5, we examine the relation between short- and long-term ownership and underinvestment in labor for subsamples of firms with different probabilities of earnings manipulation. We proxy for the probability of earnings manipulation using the M-score (Beneish, 1999). For each year, we define firms with below- (above-) median M-score as likely (unlikely) manipulators. All regressions include year and industry fixed effects. All variables are defined in Appendix A. The $t$-statistics in parentheses are based on robust standard errors clustered at the firm level. ***,**, and * denote statistical significance at the $1 \%, 5 \%$, and $10 \%$ levels, respectively.

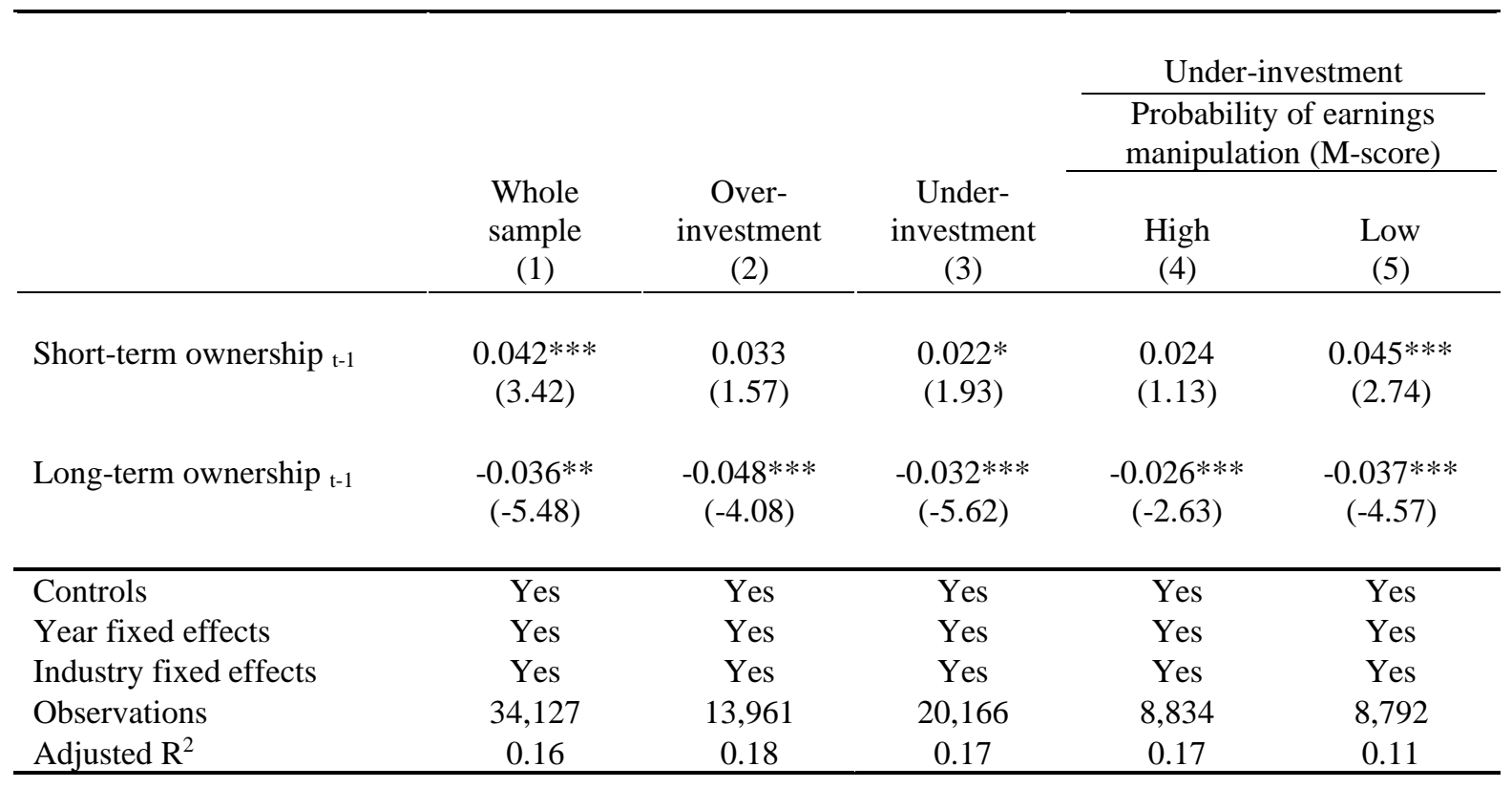

